Balkan Araştırma Enstitüsü Dergisi / Journal of Balkan Research Institute Cilt/Volume 10, Sayı/Number 1, Temmuz/July 2021, ss. 221-266.

Geliş - Received: 11.09.2020

Kabul - Accepted: 10.02.2021

DOI:

ARAȘTIRMA MAKALESI - RESEARCH ARTICLE

OSMANLI DEVLETİ İLE SIRBISTAN ARASINDA “OYNAK SINIR": TIMOK NEHRI'NİN MECRASININ DEĞİŞMESİ VE KARŞILAŞILAN SORUNLAR (1849-1874)

Gürsoy ŞAHIN*

ÖZ

Araştırmanın amacı Sırbistan ile Osmanlı Devleti arasında sınır teşkil eden Timok Nehri'nin aşırı yağmurlar sebebiyle taşması sonucunda "oynak sınır" oluşumu ve buna bağlı olarak ortaya çıkan sorunları irdelemektir. Timok Nehri'nin 1849 yılında yağmurlar sebebiyle yatak değiştirmesi, sınırda bulunan Berkofça köyündeki Osmanlı ahalisinin topraklarının Sırp tarafında kalmasına sebep olmuştur. Bilahare 1872 yılında taşkına sebep olduğu gerekçesiyle nehir kenarındaki Osmanlı ahalisine ait değirmenlerin bendleri Sırplar tarafından yıkılmış, aynı zamanda nehrin yatağı da değiştirilmiştir. Bunun üzerine Baley köyündeki Osmanlı ahalisinin arazileri Sırp tarafında kalmıştır. Taraf hükümetleri, ahali arasında yaşanabilecek çatışmaları önlemek için karma bir komisyon oluşturarak sınır meselesini çözmeye çalışmıştır.

Anahtar Kelimeler: Sınır, Sırbistan, Timok Nehri, Osmanlı Devleti, Bulgaristan

"THE UNSTABLE BORDER" BETWEEN THE OTTOMAN EMPIRE AND SERBIA: DRAIN CHANGE OF THE TIMOK RIVER AND THE ENCOUNTERED PROBLEMS (1849-1874)

\begin{abstract}
The aim of this research was to investigate the formation of an "unstable border" due to the flooding of the Timok River whih served as the border between Serbia and the Ottoman Empire due to heavy rainfalls and the resulting problems. The fact that the Timok River changed the river bed due to rain in 1849 meant that
\end{abstract}

* Prof. Dr., Afyon Kocatepe Üniversitesi, Fen-Edebiyat Fakültesi Tarih Bölümü, Afyonkarahisar, ORCID: orcid.org/0000-0002-7817-2043, E-posta: gsahin@aku.edu.tr 


\section{GÜRSOY ŞAHIN}

the land of the Ottomans, who lived in the village in Berkofça on the border remained on the Serbian side. Afterwards, for the reason that it caused the flood in 1872 , the dams of the mills on the banks of the river, which belonged to the Ottoman people were demolished by the Serbs, and the river bed was also changed. Thereupon, the lands of the Ottoman people in Baley village were left on the Serbian side. Governments tried to solve the border issue by establishing a mixed commission to prevent the conflicts that might arise within the community.

Keywords: Border, Serbia, Timok River, Ottoman Empire, Bulgaria

\section{Giriş}

Devletler hukuku açısından sınır; bir devletin ülkesini diğer devletlerin topraklarından veya sahipsiz bir araziden yahut açı denizden ayıran farazi bir çizgidir. Ülkelerin sınırları suni ve tabii sınırlar olmak üzere ikiye ayrılmaktadır. Suni sınırlar, doğal sınırların dikkate alınmaması ya da doğal sınır teşkil edecek yer şekillerinin bulunmaması sebebiyle belirli esaslar çerçevesinde saptanırdı. Bu tür sınırlar, enlem ve boylam dereceleri esas alınarak (jeodezik) veya eğriler, düz hatlar ve yarım daireler gibi çeşitli geometrik modellemeler esas alınarak belirlenirdi. Tabii sınırlar ise iki ülke arasındaki dağlar, göller, çöller ve nehirler gibi doğal unsurlar göz önünde tutularak çizilen sınırlardı. Tabii sınırların en belirgini dağ veya sıradağlardı. Sınırların belirlenmesinde başvurulan doğal işaretlerden bir diğeri akarsulardı. Sınır oluşturan akarsular, sınırın tespiti bakımından çeşitli özellikler taşımaktaydı. Zira akarsu yatakları zaman zaman değiş̧ebildiği için genişliği ve derinliği bakımından sabit ölçülerde değildi. Bu bakımdan akarsular "oynak sınır hatları" olarak kabul edilmektedir. ${ }^{1} \mathrm{Bu}$ anlamda 1833'ten itibaren Osmanlı Devleti ile Sirbistan arasında sinır olarak tespit edilen Timok Nehri'nin 1849'dan itibaren aşırı yağmurlar sebebiyle taşması ve akabinde ortaya çıkan sorunlar, oynak sınır tartışmalarıyla ilgili ilginç bir örneklik oluşturmaktadır.

Malum olduğu üzere Osmanl1-Sırp ilişkilerinin geçmişi XIV. yüzyıla kadar gitmektedir. XV. yüzyılda Osmanlı egemenliğine dahil edilen Sırp toprakları, XIX. yüzyılın başlarına kadar Osmanlı yönetiminde kaldı. ${ }^{2}$

1 Bahadır Apaydın, "5 Aralık 1857 Tarihli Osmanlı Devleti-Rusya Sınır Anlaşması", Uluslararası Hukuk ve Politika, Cilt 5, Sayı 18, 2009, s. 85-87.

${ }^{2}$ Barbara Jelavich, Balkan Tarihi, 18-19. Yüzylllar, çev. İ. Durdu-H. Koç-G. Koç, 2. Bask1, Küre Yay., İstanbul 2009, s. 32, 42, 218; A. Hajek, "Sırbistan", İslam Ansiklopedisi, 10, MEB Yayınları, İstanbul 1980, s. 560. 


\section{OSMANLI DEVLETI İLE SIRBISSTAN ARASINDA “OYNAK SINIR”: TIMMOK NEHRI'NİN MECRASININ DEĞİSMESİ VE KARŞILAȘILAN SORUNLAR (1849-1874)}

Bu makalenin konusunu oluşturan Timok Nehri, Bulgaristan coğrafyasında Vidin sancağının Vidin kazasına bağlı bir nahiye olan Timok'la aynı adı taşıyan bir nehirdir. Vidin Prensliği, Yıldırım Bayezid'ın Niğbolu'da Haçlı ordularını bozguna uğratıp Prens İvan Sracimir'i Bursa'ya götürmesi ile Osmanlı Devleti'ne katıldı. ${ }^{3}$

Osmanlı'nın kuzey sınırını korumak için bir kale işlevi gören Vidin şehri, Tuna Nehri'nden gelebilecek muhtemel saldırılara karşı da bir üs olarak kullanılmaktaydı. Fetihten sonra Anadolu'dan gelen Türk göçmenler iskân edilmekle birlikte şehir çoğunlukla Hristiyanların yaşadığı bir bölge olarak kaldı. ${ }^{4}$ Farklı kaynaklara göre ise XVI. yüzyılda Müslüman nüfusun gayrimüslimlere oranla $\% 23$ arttığı Vidin, tam bir Türk-Osmanlı şehri görünümüne kavuştu. ${ }^{5}$ Şehir, Macarlar ile Habsburgların savaşları sırasında çeşitli kereler saldırılara uğramış ve her seferinde tahrip olmuştu. Vidin, Karlofça Antlaşması'na (1699) göre Osmanlılara birakıldı. ${ }^{6} 1714$ yılında başlayan Osmanl1-Avusturya savaşları 1718'de Pasarofça Antlaşması ile sona erince Vidin sancağının kuzeybatı kısmı yani Timok bölgesini içerecek şekilde bütün Kuzey Sirbistan, Osmanlı idaresinden Habsburg İmparatorluğu'na geçti. ${ }^{7} \mathrm{Bu}$ süreçte Osmanlı yöneticileri buradaki kaleyi daha da güçlendirdi. ${ }^{8}$

1701 y1lında Vidin'in kazaları Bane, İsferlik, Polmiye ve Timok'tu. ${ }^{9}$ 1795-1807 yılları arasında Pazvandoğlu Osman tarafindan yönetilen şehirde $^{10}$ Pazvandoğlu'nun zirai mülkleri Sahra, Girbune ve Timok mukataalarında bulunan arazi ile değirmen, çiftlik ve çayırlardan

\footnotetext{
${ }^{3}$ Machiel Kiel, "Vidin", Diyanet İslâm Ansiklopedisi (DIA), Cilt 43, TDV Yay., İstanbul 2013, s. 103-104.

${ }^{4}$ Kiel, a.g.m., s. 104.

${ }^{5}$ Hava Selçuk, Tuna Boyunda Bir Osmanlı Kenti Vidin -XIX.Yüzyıl-, Çizgi Kitabevi, Konya 2013, s. 25.

${ }^{6}$ Kiel, a.g.m., s. 105.

7 İsmail Hakkı Uzunçarşılı, Osmanlı Tarihi, (Karlofça Antlaşmasından XVIII. Yüzyılın Sonlarına Kadar), Cilt IV, 1. Kısım, 7. Bask1, TTK Yay., Ankara 2011, s. 144; Uğur Kurtaran, "Pasarofça Antlaşması'na Göre Yapılan Sınır Tahdit Çalışmaları ve Belirlenen Yeni Sınırlar", Uluslararası Sosyal Araştırmalar Dergisi, Cilt 11, No. 55, (Şubat 2018), s. 285-300.

${ }^{8}$ Kiel, a.g.m., s. 105.

${ }^{9}$ Mahir Aydın, Vidin Kalesi: Tuna Boyu'ndaki İnci, Ötüken Yay., İstanbul 2015, s. 75.

${ }^{10}$ Kiel, a.g.m., s. 105.
} 


\section{GÜRSOY ŞAHIN}

oluşmaktaydı. ${ }^{11}$ Toprakları son derece verimli olan Vidin şehri buğday, üzüm, bal ve et açısından da son derece zengindi. Kale dışındaki toprak sahibi Bulgarlar, tarım ve hayvancılıkla uğraşmaktaydı. ${ }^{12}$ Kırım Savaşı'ndan önce Vidin kazası altmış dört köyü kapsamakta, Türkçe konuşan Müslüman ahali sadece Vidin şehri ile Akçar ve Florentin köylerinde yaşamaktaydı. ${ }^{13}$

1804 yılında Osmanlı idaresine karşı isyan eden Sırplar, bağımsızlık tarihlerinde Timok bölgesinin Osmanlı idaresinden kurtarılmasına büyük önem atfetmektedir. Sirplar, 1804'te Şumadiya'da başlattıkları isyanı müteakip Timok bölgesini kurtarmak için harekete geçmişlerdi. Üç sene devam eden mücadele sonunda Velko Petroviç adındaki bir sergerdenin idaresindeki asiler Türk kuvvetlerine hücum ederek 1807'de mahalli bir zafer kazanmış, 1810 yılında ise Türk kıtalarını bölgeden tamamen çıkarmışlardı. Bölge 1813'te tekrar Osmanlı kuvvetleri tarafından kontrol altına alınmış, o sırada haydut Velko Petroviç de burada ölmüştü. Böylece Timok havalisi Vidin'e bağlanmıştı. ${ }^{14}$

Rusya'nın desteği ile 1829 Edirne Antlaşması akabinde Sırplara özerklik yolunda yeni haklar tanınd $1 .{ }^{15}$ Bilahare 17 Ekim 1830 'da verilen bir imtiyaz fermanıla Osmanlı yönetimi, Sırpların muhtariyetini tanıdı ve Sırplar içişlerinde bağımsız bir prenslik haline geldi. ${ }^{16} \mathrm{Bu}$ muhtariyetin ardından II. Mahmud tarafından Sırbistan'a yeni topraklar verilmiştir ki bu alanlardan birisi de Timok'tu. 1832'de Prens Miloş’un Kruşevaç bölgesinde gerçekleştirdiği isyan başlangıçta engellendi. ${ }^{17}$ Ancak bilahare Sırp Prensliği tarafından asilere gönderilen kuvvetlerin yardımı ile Türk askerleri bölgeyi terke mecbur kaldı. Böylece 1833'de Timok'un Sirp Prensliğine ilhakı resmiyet kazand $1 .{ }^{18}$ Sonuçta Timok Nehri, Osmanlı Devleti ile Sırp Prensliği

11 Nagehan Üstündağ Özdemir, 18. Yüzyılda Vidin Şehrinin Sosyo-Ekonomik Panoraması (1790-1808), Hacettepe Üniversitesi Sosyal Bilimler Enstitüsü Tarih Anabilim Dal1, Basılmamış Doktora Tezi, Danışman: Prof. Dr. Yunus Koç, Ankara 2014, s. 288.

${ }^{12}$ Aydın, a.g.e., s. 150; Ayşe Kayapınar, "Ortaçağ ve Osmanlı Döneminde Vidin”, Ege ve Balkan Araştırmaları Dergisi, Cilt 2015, Sayı 1, s. 101.

${ }^{13}$ Kiel, a.g.m., s. 105.

${ }^{14}$ BCA, 030.10.00.00/251.696.11.7.

15 Şerafeddin Turan, "1829 Edirne Antlaşması”, Ankara Üniversitesi Dil ve Tarih-Coğrafya Fakültesi Dergisi, Cilt 9, Sayı 1-2, 1951, s. 111-151.

${ }^{16}$ Halil Kurt - Mehmet Hacisalihoğlu, "Sirbistan", DIA, Cilt 37, TDV Yay., İstanbul 2009, s. 123.

${ }^{17}$ BCA, 030.10.00.00/251.696.11.7.

${ }^{18}$ Hatta 1933 yılında bölgenin Türklerden kurtarılışının 100. Yıldönümü kutlanmış, bu sırada gerçekleştirilen sinema filmi gösterimine Türkiye tepki göstermiştir. BCA, 030.10.00.00/251.696.11.8. 


\section{OSMANLI DEVLETI İLE SIRBISSTAN ARASINDA “OYNAK SINIR”: TIMMOK NEHRI'NİN MECRASININ DEĞIŞMESİ VE KARŞILAŞILAN SORUNLAR (1849-1874)}

arasında sınır olarak kabul edildi. Bu dönemde Sırbistan olarak tanımlanan bölge; doğuda Timok Nehri, batıda Drina Nehri, kuzeyde Sava ve Tuna nehirleri, güneyde Şar Dağları arasında kalan bölgeden oluşmaktaydı. ${ }^{19}$

Çalışmada Sırbistan ile Osmanlı Devleti arasında sınır olarak tespit edilen Timok Nehri'nin 1849 yılından itibaren aşırı yağmurlar sonucu taşması ve mecrasının değişmesiyle ortaya çıkan sınır problemleriyle bu sorunların giderilmesine yönelik çabalar Osmanlı arşivindeki belgeler 1şığında ortaya konulmaya çalışıldı. Keza nehir kenarındaki değirmenlerin bendlerinin taşkınlara sebep olduğu gerekçesiyle 1872 yılında Sırplar tarafından yıkılması ve nehrin yatağının değiştirilmesi ve Osmanlı ahalisinin arazilerinin Sırp tarafinda kalması da değerlendirildi.

\section{1849 Yılında Timok Nehri'nde Yaşanan Taşkın ve Ortaya}

\section{Çıkan Sorunlar}

Avrupa'nın Amazonu olarak da tanımlanan Tuna Nehri, yüzyıllar boyunca Avrupa kıtasının hem tabiatını hem de medeniyetini etkilemiş bir nehirdir. Yaklaşık 3 bin kilometre uzunluğundaki Tuna Nehri'ne Belgrad'1 geçtikten sonra birçok akarsu katılmaktadır. $\mathrm{Bu}$ nehirlerden üç büyüğü Vidin'in batısındaki Sava, Morava ve Timok Nehirleridir. ${ }^{20}$ Araştırma konusunu oluşturan Timok Nehri, günümüzde $202 \mathrm{~km}$ uzunluğu ile Doğu Sirbistan'in en büyük nehri olup Tuna'nın Sirbistan'daki son koludur. ${ }^{21}$ Salnamelerde de Timok Nehri'nin Sirbistan'dan çıkıp Vidin kazasında Rakofça-i Sağir köyünün alt tarafında Tuna Nehri'ne karıştığı ifade edilmektedir. ${ }^{22}$

Halen Sirbistan Cumhuriyeti topraklarından akan nehir, Bregovo'da $17,5 \mathrm{~km}^{23}$ boyunca Doğu Sirbistan ile Batı Bulgaristan arasındaki sınırı

\footnotetext{
19 Nurbanu Duran, Sirbistan Emareti Öncesi Belgrad: 1792-1830, İstanbul Üniversitesi Sosyal Bilimler Enstitüsü, Basılmamış Doktora Tezi, Danışman: Prof. Dr. Mahir Aydın, İstanbul 2019, s. 7-8.

${ }^{20}$ Aydin, a.g.e., s, $15,17$.

${ }^{21}$ Jovana Brankov, Dragana Milijašević, Ana Milanović, "The Assessment of The Surface Water Quality Using The Water Pollution Index: A Case Study of The Timok River (The Danube River Basin), Serbia”, Archives of Environmental Protection, Vol. 38, No. 1, 2012, s. 50-51.

${ }^{22}$ Salnâme-i Vilayet-i Tuna, 1. Defa, Tuna Vilayeti Matbaas1, 1285/1868 s. 120; Salnâme-i Vilayet-i Tuna, 6. Defa, Matbaa-i Vilayet-i Tuna, Rusçuk 1290/1873, s. 322.

${ }^{23}$ United Nations. Economic Commission for Europe, Rainer Enderlein, Our Waters: Joining Hands Across Border First Assessment of Transboundary,
} 


\section{GÜRSOY ŞAHIN}

oluşturur. Karadeniz havzasının bir parçası olan Timok Nehri'nin ortalama akış hızı $24 \mathrm{~m}^{3} \mathrm{~s}-1$ ve maksimum $40 \mathrm{~m}^{3} \mathrm{~s}-1$ olarak tespit edilmiştir. ${ }^{24}$ Coğrafi açıdan nehir havzası $43^{\circ} 15^{\prime}$ ve $44^{\circ} 15^{\prime}$ kuzey enlemi ve $21^{\circ} 30^{\prime}$ ve $22^{\circ} 45^{\prime}$ doğu boylamı arasinda yer almakta ve $4.547 \mathrm{~km}^{2}$ lik bir alanı kaplamaktadır. ${ }^{25}$ Tuna, Timok ve bölgedeki diğer nehirlerin su potansiyelinin çok fazla olduğu anlaşılmaktadır. Örneğin Tuna Nehri'nin aşırı yağmurlar sonucunda bir gecede $10 \mathrm{~m}$. yükselebildiği kaynaklarda ifade edilmektedir. Suyun bol olmasının sonucunda toprağın verimliliği başta olmak üzere su değirmeni, su dolabı, çiftlik ve kovanlık alanlar gibi kaynaklar elde edilmiştir. ${ }^{26}$

\subsection{Sınır Sorununun Ortaya Çıkması}

Surbistan'a muhtariyet verilmesi ve 1833'ten itibaren Timok'un Sirp Prensliğine ilhakı bu tarihlerden sonra Osmanlı Devleti ile Surbistan arasındaki sınır problemlerini beraberinde getirmiştir. Timok Nehri'nin taşması sonucunda nehir yatağının değişmesi ve Osmanlı ahalisinin bazı tarla ve çayırlarının Sırp tarafinda kalması iki taraf ahalisi arasında gerginliğe neden olmaktaydı. Sırb tarafının Osmanlı ahalisine karşı tutumu ve ahalinin arazisini kullanamaması, büyük bir infial yaratmaktaydı. Olay giderek çıkmaz hale gelince bölge ahalisi bir arzuhalle yaşadıkları sorunları dile getirdi.

Sorunla ilgili tespit edilen ilk arşiv belgesi 1849 yılının ilk günlerine aittir. Belgede ifade edildiği üzere Osmanlı toprağ nahiyesine bağlı Berkofça köyünden bir grup ahali bir arzuhal kaleme aldı. 11 Ocak 1849 tarihli belgede, kesin tarih bildirilmemekle birlikte bir süre önce Timok Nehri'nin aşırı yağmurlar sebebiyle taşdığı, bunun sonucu olarak nehrin yatağının değiştiği ve köy ahalisinden altmış üç kişinin tarla ve çayırlarının Sırbistan tarafında kaldığından söz edilmekteydi. Ahali dilekçede, taşkının daha önce (muhtemelen 1847'de (H.1263))

https://www.unece.org/fileadmin/DAM/env/water/blanks/assessment/assessmentweb full.pdf, (03.09.2020).

${ }^{24}$ Radmila Pivić vd., "Water from the Timok River in Serbia: Estimation of Its Suitability for Arable Soil Irrigation", 23rd International Symposium on Analytical and Environmental Problems, October 9-10, 2017, Edt: Tünde Alapi - István Ilisz, Szeged, Hungary 2017, s. 283-288. http://www2.sci.u-

szeged.hu/isaep/index_htm_files/Proceedings_of_ISAEP_2017.pdf, (04.09.2020).

${ }^{25}$ Brankov, Milijašević, Milanović, a.g.m., s. 50-51.

${ }^{26}$ Aydın, a.g.e., s. 15-16; Üstündağ Özdemir, a.g.t., s. 81-82, 126. 


\section{OSMANLI DEVLETI İLE SIRBISSTAN ARASINDA “OYNAK SINIR”: TIMMOK NEHRI'NİN MECRASININ DEĞİȘMESI VE KARŞILAȘILAN SORUNLAR (1849-1874)}

gerçekleştiğini, aynı yılın yaz aylarında herhangi bir engelle karşılaşmadan Sirp tarafinda kalan tarlalarında ziraata devam ettiklerini ancak 1848 (H.1264) yılı yaz aylarından itibaren hayvan hastalığı olduğu gerekçesiyle Sırp yetkililer tarafından sınıra bir karakol yapıldığını ve kimsenin geçmesine izin verilmediğini bildirmekteydi.

Taşkından bir süre sonra yaşanan gelişmeler Osmanlı ahalisini daha da sıkıntıya sokmuştu. Zira 1849 (H.1265) yılında Osmanlı tebaasının mülkü olan arazilere Sırp zabitler tarafindan el konulmaya ve Sirp ahaliye taksim edilmeye başlanmıştı. Osmanlı ahalisi bu yapılanlar karşısında uğradıkları haksızlığın ve yanlışın düzeltilmesi amacıyla üç kez mahalli yöneticilere arzuhal vererek, tarla ve çayırlarının Sırp tarafına geçtiğini bildirdi. Ancak Sırp yöneticiler tarafından meseleyle ilgili herhangi bir cevap verilmeyip konu sürüncemede bırakıldı. Bunun üzerine tekrar dilekçe veren ahali, "Sırb tarafina mı göç edelim, yoksa ecdadımızdan kalan hanelerimizi terk edip nereye gidelim" sorusunu sorarak mevcut duruma serzenişte bulundu. Ahali adına Alemdar ve Herdasa adlı kişiler arzuhalin sonunda tarla ve çayırlarının kurtarılması hususunda taleplerini tekrarladı. ${ }^{27}$

Ahalinin dilekçesi üzerine Vidin valisi Hüseyin Paşa, 11 Ocak 1849'da Bâbıâli'ye gönderdiği yazıda Timok Nehri'nin taşması ve akabinde yaşanan durumu arz etti. Yazıda, Berkofça köyü ahalisinin şikayetleri aktarıldı. Bu kapsamda nehrin taşkınından dolayı ahalinin tarla ve çayırlarının önemli bir kısmının Sırp toprakları tarafında kaldığı, benzer şekilde Sırp ahalisinden bir kısmının çayırlarının da Vidin tarafında bulunduğu dile getirildi. Belgede çayırları Osmanlı tarafinda kalan Sırp ahalisine çayırlarını kullanma konusunda herhangi bir engel çıkarılmadığı ifade edilmekteydi. Hukukun gereği olarak Berkofça köylülerinin de tarla ve çayırlarını kullanmalarına izin verilmesi ve Sırp yetkililerinin Osmanlı ahalisinin topraklarını "zabt etmek sevdasından vazgeçmeleri" gerektiği birkaç defa Sırp emaretine yazılmıştı. Ancak Sırp yetkililer hiçbir şekilde cevap vermedi. Yazıda Sirpların son zamanlarda Osmanlı tebaasının tarla ve çayırlarını taksim etmeye niyetlendikleri hatırlatılırken, bu durumun sorunu daha da büyütebileceği ve Sırp ahalisine karşı düşmanlığa sebep olabileceği dile getirildi. Sonuç olarak Berkofça köyü ahalisinin tarla ve çayırlarına

\footnotetext{
${ }^{27}$ BOA, A.MKT., 196/49, 2-1; Gönderilen arzuhal zarfının üzerinde bu hususun Sirp idaresi ile müzakere edildikten sonra alınacak cevabın Berkofça köyü ahalisine iletilmesi kaydı düşüldü. BOA, A.MKT., 196/49, 3-1.
} 


\section{GÜRSOY ŞAHINN}

gerçekleşen müdahalenin sona erdirilmesinin gerektiği ve bu durumun Dersaadet'te bulunan Sirp kapı kethüdasına bildirilmesi istendi. ${ }^{28}$

\subsection{Sınır Sorununun Çözümüne Yönelik Çalışmalar}

Osmanlı sinırlarına Sirpların müdahalesinin engellenmesi hususu ve yapılması gerekenler hükümet yetkilerince müzakere edilmeye başlandı. Problemin birkaç kez Sirp idaresine yazıldığı ve henüz bir cevap alınamadığı, bu sebepten konunun söz konusu idare ile tarafsız bir şekilde müzakere edilerek neticelendirilmesi kararlaştırıldı. ${ }^{29}$ Bu bağlamda 9 Mayıs 1849'da Bâbıâli'den Vidin valisine gönderilen yazıda Timok Nehri'nin taşmasından faydalanarak Sahra nahiyesine bağlı Berkofça köyü ahalisinin tarlalarını zapteden Sırp yetkililerle tekrar görüşülmesine dair emir verildi. Belgede sorun özetlenerek Sırp ahalisinin Vidin tarafında kalan arazilerini kullanmasına karışılmadığı, aynı şekilde Sırpların da Sahra nahiyesine bağlı Berkofça köylülerinin taşkın sebebiyle karşı tarafta kalan arazilerinin ziraatına karışılmaması gerektiği bildirildi. Keza ahalinin eskiden beri işledikleri tarla ve çayırlarına sahip çıkmaları konusunda herhangi bir engel çıkarılmaması hakkında emir verildi. ${ }^{30}$

Sorunla ilgili yazışmaların ve müzakerelerin uzunca bir süre devam ettiği görülmektedir. $\mathrm{Bu}$ anlamda 1852 y1lına ait belgelerde Timok Nehri'nin mecrasının değişmesiyle arazileri Sırbistan'da kalan reayanın zararlarının giderilmesi hususu müzakere edilmeye devam edildi. ${ }^{31}$ Konu 18 Haziran 1852 Perşembe günü toplanan Meclis-i Vükela gündemine geldi. Müzakereler sırasında taşkın sonucunda söz konusu arazinin Sırp tarafında kaldığı, bununla birlikte uygulanmakta olan karantina ve diğer sebepler ile Sırp yönetimi ve ahalisinin bağlılığına da halel getirmemek için bu yerlerin bedelinin sahiplerine verilerek satın alınıp Sırp tarafına bırakılması ihtimali dile getirildi.

Meclis-i Vükela'da esasen Sırp arazisinin de Osmanlı Devleti'nin mülkü olduğu ancak idaresinin bir imtiyaz halinde bulunduğu ve vergisinin de suret-i maktua şeklinde olduğundan bahsedilmişti. Keza söz konusu arazinin kiracısı konumunda olan reayanın arazilerini satıp akçelerini almaları konusunda bir mahzur görmeyebilecekleri bildirilmekteydi. Ancak

\footnotetext{
${ }^{28}$ BOA, A.MKT., 196/49, 1-1.

${ }^{29}$ BOA, A.MKT., 196/49, 4-1.

${ }^{30}$ BOA, A.MKT., 163/47, 1-1.

${ }^{31}$ BOA, A.AMD., 41/20, 1-1.
} 


\section{OSMANLI DEVLETI İLE SIRBISSTAN ARASINDA “OYNAK SINIR”: TIMMOK NEHRI'NİN MECRASININ DEĞİSMESİ VE KARŞILAȘILAN SORUNLAR (1849-1874)}

konu müzakere edilirken, söz konusu arazilerin Sırplara birakılmasının mahallince olumsuz sonuçları olacağı bildirilerek nehrin bundan sonra yine taşkın sonucu mecrasını değiştirme ihtimali dile getirildi. Zabtiye Müşiri Hayreddin Paşa, mevcut şartlarda verilecek kararın bilahare gerçekleşecek mecra değișmelerine de emsal olușturacağını bildirdi. Ayrıca söz konusu arazinin epeyce bir yer olduğu, bu arazinin Sırbistan'a bırakılması halinde alınan vergilerin azalacağı, ayrıca reayanın ziraat alanlarının ellerinden çıkacağı ve oranın öşür ve diğer gelirinden de hazinenin mahrum kalacağı mütalaasında bulunarak buna müsaade edilmemesi gerektiğini dile getirdi. ${ }^{32}$

Belgelerde ifade edildiği üzere köy ahalisinden altmış üç kişinin tarlalarının Sırp tarafinda kaldığı, bahsedilen arazinin tespit edilerek sahiplerine teslim edilmesi ve sorunun çözülmesi hususunda daha önce Bâbıâli'den Sırp yetkililere tahrirat yazılmıştı. Ancak bir cevap alınamadı. ${ }^{33}$ Meclis-i Vükela'nın müzakereleri sırasında, 3 Ağustos 1852 tarihinde Sadrazam Koca Mustafa Reşid Paşa tarafından da ihtilaflı arazinin tespit edilmesi ve gerçek sahibi olan ahaliye teslim edilmesi konusunda bir tahrirat gönderildiği ifade edildi. Belgede köy ahalisinin arazisinden epeyce bir yerin Sırbistan tarafinda kaldığı, ahalinin mülkü ve hakları olan bu yerlerin kendilerine terk ve teslim edilmesinin hakkaniyetin gereği olduğu bildirildi. Öte yandan Sırp milletine padişahın ihsanı olarak verilmiş olan imtiyaz gereğince Sırbistan'ın sınırlarının belirli bir usul çerçevesinde belirlendiği de zikredildi.

Osmanlı ahalisinin Sirp tarafinda kalan topraklarını kullanamamasının nedenlerinden birisi olarak Sirpların karantina uygulamas1 gösterilmekteydi. $\mathrm{Bu}$ kapsamda Sirplar, topraklarının muhafazası ve millete hizmet maksadiyla belirli mahallerde karantinahaneler oluşturmuş, farklı ülkelerden Sirbistan'a gelecek olanların karantinada bekletilmesi kuralı konulmuştu. Buna göre ülke dışından gelenlere uygulandığı gibi Berkofça'dan tarlalarına gitmek isteyen ahalinin de karantinada beklemesi ve sadece belirli alanlardan ülkeye girip çıkmaları gerektiği dile getirildi. Bu durum ise tarla ve çayırlarına gitmek isteyen ahalinin çeşitli şekillerde alıkonulmasına ve bekletilmesine sebep olmaktaydı. Müzakereler sırasında bu tür sorunların ve tartışmaların yaşanmaması için Timok civarındaki ahalinin arazilerini işlemek ve ziraat etmek için "her nereden isterlerse geçmelerine irade-i ruhsat olunması"

32 BOA, A.AMD., 41/20, 1-1.

${ }^{33}$ BOA, A.AMD., 41/20, 1-1. 


\section{GÜRSOY ŞAHIN}

şeklinde bir yaklaşımın yürürlükte olan nizamnameleri ortadan kaldıracağı, karantina usulü ve nizamını tamamen bozacağı değerlendirmesi yapıldı. Keza bu durumun iki taraf yönetimleri tarafindan da kabul olunamayacağının nizamnamelerde açıç̧a belirtilmiş olduğu hatırlatıldı. Diğer taraftan söz konusu tarlaların Berkofça köyü ahalisine teslim edilmeyip hiçbir şey yapılmadan öylece bırakılması halinde de büyük bir haksızlık yapılmış olacağı ve zarara sebebiyet verileceği, bu durumun ise Osmanlı yönetim anlayışına aykırı olacağı ifade edildi. ${ }^{34}$

Netice itibariyle sorunun, hem yürürlükteki nizamnamelere uygun hem de Berkofça köyü ahalisine bir merhametsizlik yapılmadan ve zarara sebep olmadan çözümlenmesinin gerektiği ifade edildi. Bunun ise ancak ahalinin kendi rızalarıyla söz konusu tarlaları Sırp ahalisine satarak bedellerini alması şeklinde sonuçlandırılmasıyla mümkün olacağı dile getirildi. Sadaret makamı tarafından şayet bu öneri uygun görülürse Vidin valisi Hüseyin Paşa tarafından gerekli işlemlerin yapılabileceği bildirildi. ${ }^{35}$

\subsection{Sinır Sorununun Sonucu}

Meclis-i Vükela'nın müzakereleri sonucunda konunun çok yönlü değerlendirilmesi, sorunla ile ilgili gerekli incelemeleri yapmak için bir memur ve özel bir mühendis görevlendirilmesi kararlaştırıldı. Bu görevlilerin gerek bahsi geçen yerleri ve gerekse daha önceki taşkınlar sebebiyle gerçekleşen mecra değişiklikleri ile sınırdaki çitin eski mevkiinini incelemesi, arazinin verimine bakılması ve Sirp tarafina da bir yazı yazılarak oradan da memurların görevlendirilmesinin tavsiye edilmesi uygun görüldü. ${ }^{36}$

Verilen karar üzerine Seraskerlik makamına bir yazı yazıldı. Yazıda sorundan bahsedildikten sonra Sirp tarafindan gelen cevap hakkında müzakerelerde bulunmak, bölgede gerekli tespit ve keşfi yapmak için bir memur ve bir mühendisin görevlendirilerek Vidin'e gönderilmesi gerektiği bildirildi. ${ }^{37}$ Bunun üzerine iki topçu binbaşısıyla Mühendishâne-i Berrî-i Hümâyun Birinci Kaymakamı Hacı Mehmed Sadık Bey görevlendirildi. ${ }^{38}$ Gerekli yazışmaların ardından 19 Mayıs 1853'de Osmanlı ile Sırp memur ve

${ }^{34}$ BOA, I.DH., 262/16258, 1-1.

${ }^{35}$ BOA, I.DH., 262/16258, 1-1.

${ }^{36} \mathrm{BOA}, \dot{I} . D H ., 262 / 16258,2-1$.

${ }^{37}$ BOA, A.MKT.NZD., 68/5, 1-1.

${ }^{38}$ BOA, HR.MKT., 238/99, 1-1. 


\section{OSMANLI DEVLETI İLE SIRBISSTAN ARASINDA “OYNAK SINIR”: TIMMOK NEHRI'NİN MECRASININ DEĞİŞMESİ VE KARŞILAŞILAN SORUNLAR (1849-1874)}

mühendislerinden oluşan komisyon, Timok Nehri'nin eski mecrası ile yeni durumu gösteren bir haritayı ortaklaşa hazırladı. ${ }^{39}$ Komisyon haritay1 hazırlamış olsa da konunun Kırım Savaşı sebebiyle sürüncemede kaldığı anlaşılmaktadır.

Sorun 1858 y1lında yeniden gündeme geldi. Konuyla ilgili Tophanei Amire Müşirliğine yazılan 24 Mayıs 1858 tarihli tezkerede Timok Nehri'nin mecrasının değişmesinden dolayı Berkofça köyü ahalisinden altmış üç nefer Hristiyan'ın arazisinin Sırp tarafına geçmiş olduğu hatırlatıldı. Tezkerede 1853 senesinde iki topçu binbaşısıyla Mühendishânei Berrî-i Hümâyun Birinci Kaymakamı Hacı Mehmed Sadık Bey’in, Sırp tarafının memurları ile birlikte ihtilaflı yerin haritasını hazırlayarak Bâbıâli'ye teslim ettikleri bildirildi. Söz konusu haritanın 1858 yılında halen kalemde mevcut olduğu anlaşılmakla birlikte belgeler arasında harita dışında herhangi bir rapor tespit edilemedi. Bu sebepten konunun Divan-1 Hümayun'da müzakereleri sırasında Kaymakam Sadık Bey'in bölgeyle ilgili tespit ve gözlemlerini bizzat aktarmak için hazır bulunması istendi. ${ }^{40}$ Öyle anlaş1lyyor ki mesele prensipte çözülmüş ancak pratikte farklı sorunlar devam etmiști. Şöyle ki arazinin yer tespiti yapılmış, belirli işaretler konularak Berkofça ahalisinin ziraat etmeleri uygun görülmüştü. İlk sene Sırp hükümeti bu duruma izin vermiş ancak ertesi sene köyün on sekiz saat uzağında Rakovica iskele geçidinden dolaşıp pasaportla geçtikten sonra ziraat etmeleri gerektiği ifade edilmişti. Bu durumun uygulanmasının mümkün olamadığı anlaşılınca ahali arazilerini hukuken kaybetmemek için topraklarını cüzi bir miktar karşılığında Sırplara kiralamaya başlamışlardı ${ }^{41}$

\section{1872 Yıllında Yaşanan Taşkın ve Ortaya Çıkan Sorunlar}

Timok Nehri'nin mecrasının değişmesi bir süre sonra Osmanlı ile Sırp ahalisi arasında yeniden sorun teşkil etmeye başladı. Öncelikle 1862 'de, ${ }^{42}$ bilahare 1872 yılından itibaren taraflar arasında daha öncekine benzer ihtilafların ortaya çıktığı görülmektedir. Sırp ahalisi, Timok Nehri

\footnotetext{
39 1/5000 ölçekli harita için bkz. BOA, HRT.h., 261/1.

${ }^{40}$ BOA, HR.MKT., 238/99, 1-1; BOA, HR.MKT., 248/90, 1-1; BOA, HR.MKT., 248/90, 1-2.

${ }^{41}$ BOA, HR.SYS., 1393/16, 4-2, 4-3.

${ }^{42}$ Sahra kazasına bağlı Direç köyü ahalisinin Rakofça-i Sağir (Rakoviçe-i Sağir) köyü önünde ve Timok Nehri üzerinde inşa etmiş oldukları değirmen bendine taşkına sebep olduğu gerekçesiyle Sırpların müdahalesi hakkında bkz. BOA, HR.MKT., 411/43; Bölgenin keşfi amacıyla Sırp yetkililer tarafından memurlar görevlendirildiğinin haber alınması üzerine Osmanlı yetkilileri tarafindan da Erkan-1 Harp Miralayı Tevfik Bey, Sırbistan Komiseri Ali Bey ve diğer memurlar ile keşif yapılması kararlaştırıldı. BOA, HR.MKT., 437/32, 3.
} 


\section{GÜRSOY ŞAHIN}

kıyısında bulunan Baley köyü yakınında mevcut dört adet değirmenin bendleri sebebiyle nehrin taştığını ve arazilerine zarar verdiğini ileri sürerek nehrin yatağını ve akış yönünü değiştirmişlerdi. Bunun üzerine köy ahalisinin hem önemli miktarda arazisi Sırp tarafına geçmiş hem de nehir kenarında faaliyet gösteren değirmenler atıl kalmıştı. Keza çayırlara ot biçmeye giden köy ahalisinin hayvanları karakoldaki neferler tarafindan kurşunlanarak telef edildi. Sorun ilk olarak 30 Mayıs 1872 ve 18 Haziran 1872 tarihlerinde 326 ve 396 numaralı arizalar ile hükümete bildirildi. ${ }^{43}$ Sırpların bölgeye yeni bir karakol inşa ettiği de 24 Ekim 1872 tarih ve 400 numaralı ariza ile şikayet konusu edildi. ${ }^{44}$ Köylülerin konuyla ilgili verdikleri dilekçede bildirildiği üzere yapılan incelemede Sırp ahalisinin haksız olduğu anlaşılmaktaydı. Bu sebepten Sırplar, Baley köyü ahalisinden bir miktar arazi satın almak için el altından pazarlığa girişmişler ve bin iki yüz (1.200) kadar Macar altını teklif ederek bölgede nüfuz sahibi olmaya çalışmışlardı. ${ }^{45}$

Aradan geçen zaman içerisinde Osmanlı ahalisi, dilekçelerine herhangi bir cevap alamamıştı. Bunun üzerine köylüler yeniden harekete geçti. Değirmen sahiplerinin sorununun halledilmesi için Baley köyünün muhtar-1 evveli 25 Aralık 1872 tarihinde köy ahalisi adına Vidin mutasarrıflığına tekrar dilekçe verdi. Dilekçede; Baley köyünün yüz yirmi hanelik nüfusa sahip olduğu, ahalinin köyün sınırları içerisinde olan ve çok eskiden beri sahip oldukları ata arazilerinin Timok Nehri'nin yatağı değiştirildiği için Sırp tarafinda kaldığı ve Sırp yetkililer tarafından arazinin zabt edildiği bildirildi. Bölge arazisinin son derece verimli olduğu, satılması halinde iki yüz-üç yüz bin (200-300 bin) kuruş değerinde bir bedeli olacağ1 ifade edildi. Sırp topraklarına katılan araziden sonra ellerinde kalan tarlaların, köylülerin geçimlerini temin etmeye yetmeyeceği bildirilirken nehrin köyün hemen önünden akmaya başladığı için ileride köy için büyük tehlike oluşturabileceği de dile getirildi. Dilekçede nehrin yatağının değiştirilmesinden bir süre sonra Sırp ahalisinin Baley köyündeki ahaliye arazilerini satın alma teklifinde bulunduğu da hatırlatıldı. Köylüler ise "satılık arazileri olmadiğı"nı söyleyerek teklifi reddetmişlerdi. Neticede Baley köyü ahalisi söz konusu arazinin kendilerine iadesi hususunda Sirp yetkililerine emir verilmesi talebini dile getirdi. ${ }^{46}$

\footnotetext{
${ }^{43}$ BOA, HR.MKT., 775/71, 8.

${ }^{44}$ BOA, HR.MKT., 775/71, 6 .

${ }^{45}$ BOA, HR.SYS., 1393/16, 1-1.

${ }^{46}$ BOA, HR.SYS., 1393/16, 7-1.
} 
OSMANLI DEVLETİ İLE SIRBISSTAN ARASINDA “OYNAK SINIR": TIMMOK NEHRI'NİN MECRASININ DEĞIŞMESİ VE KARŞILAŞILAN SORUNLAR (1849-1874)

Vidin mutasarrıfı tarafindan 29 Aralık 1872'de konuyla ilgili kaleme alınan yazıda, Sırpların Timok Nehri'nin doğal mecrasını değiştirerek kendi topraklarında kalan Baley köyü arazisine gerçekleşen tecavüzlerinin ortadan kaldırılması yönünde iletilen ve bir süredir tekrarlanan şikayetlere rağmen Sırp yöneticilerinden henüz bir cevap alınamadığ dile getirildi. Bunun üzerine köy ahalisinin arazilerine gerçekleşen müdahalenin önlenmesi hususunda yeniden şikayet ve talepte bulundukları bildirildi. ${ }^{47}$

Sırpların nehrin akışına müdahale ederek, akış yönünü değiştirmeleri bir nevi tecavüz sayılabilir. Bu durum ahaliler arasında da düşmanlığa neden olmaktaydı. Çünkü belgelerde ifade edildiği üzere Sırpların bölgedeki bu türden müdahaleleri daha önceki yıllarda da söz konusu olmuştur. Mesela 1869 (1285) senesi Ağustosunda Belgradçık kazasına bağlı Vilaçoviç Balkanında sınır hattının iki yüz metre ilerisinde bulunan alan Sırplar tarafından çit içine alınmıştı. Bu şekilde nehrin kaynak $^{48}$ bölgesi de bir oldu bitti ile Sırp tarafına geçmişti. Sırpların bu oldu bittileri ahali arasındaki tedirginliği daha da artırdı. Nitekim sınır bölgesinde geniş araziye sahip olan (gospodar) Süleyman Ağa'nın çayırını biçmek üzere gitmiş olan görevli, birkaç Sırp tarafından silahla yaralanmıştı ${ }^{49} \mathrm{Bu}$ tür olayların çoğunlukla zabtiyeler tarafından gerçekleştirildiği anlaşılınca bir özel komisyon kurulmasına karar verildi. ${ }^{50}$

\subsection{Sorunun Çözümüne Yönelik Girişimler: Komisyon}

\section{Oluşturulması}

Sorunun çözümü konusunda gecikmeden harekete geçildi. 21 Haziran 1872 tarih ve 198 numaralı telgrafname ile komisyonun kurulmas1 kararlaştırıldı. Ön inceleme için görevlendirilen memurlar Bregovo köyünün arazisinde ve Timok Nehri üzerinde bulunan iki adet değirmen ile Sirpların değirmenlerinin bendlerindeki ihtilafin keşf ve muayenesi hususunda gerekli araştırmaları yaparak raporlarını 29 Haziran 1872 tarihinde tamamladı. Hazırlanan takrire göre Timok Nehri'nin mecrasına Sirplar tarafindan bendler inşa ettirilerek nehrin yatağı Baley köyü önüne çevrilmişti. Sırplar, bununla da kalmamış kendi taraflarına geçen Baley köyü arazisi üzerine bir

${ }^{47}$ BOA, HR.SYS., 1393/16, 1-1.

${ }^{48}$ Bir nehrin hangi noktasında olursa olsun; kaynak yönü yukarı, akış yönü de aşağı olarak tanımlanır. Aydın, a.g.e., s. 16.

${ }^{49}$ BOA, HR.MKT., 775/71, 4.

${ }^{50}$ BOA, HR.MKT., 775/71, 3 . 


\section{GÜRSOY ŞAHIN}

de karakol inșa etmişlerdi. Köy ahalisi tarafından verilen dilekçelerde bu durum açıklanmıştı. ${ }^{51}$ Yaşanan problemle ilgili Vidin'in eski mutasarrıfı Aziz Paşa da bizzat bilgi vermişti. Buna göre Sırplar, Bregovo köyü çayırlarını kendi sınırı içerisine almak için nehrin mecrasına bir sed yaparak nehrin yönünü Baley köyünün önüne çevirmişlerdi. Ayrıca köyün karşısına bir de karakol inşa edilmişti. ${ }^{52}$

Osmanlı memurlarının yaptıkları ön keşif ve yazışmalar akabinde iki tarafin yetkililerinden oluşan bir karma komisyon kurulması kararlaştırıldı. Bu anlamda 29 Nisan 1873'te Tuna Vilayetinden Seraskerlik makamına çekilen telgrafta, Vidin kazasının Sırp sınırında ihtilaf konusu mahallerin yerinde keşfi için bir karma komisyon kurulması kararlaştırıldığı, bu komisyonda bir erkanı harp zabitinin de bulunmasının gerekli görüldüğ̈̈ bildirilmişti. Yazıda, Sırplar tarafından seçilen memurların birkaç güne kadar gönderileceği, gecikme yaşanmaması için ehliyet sahibi bir zabitin seçilerek Vidin'e hemen gönderilmesi hususunun İkinci Ordu Komutanlığına telgrafla tebliğ edilmesi talep edildi. ${ }^{53}$

Seraskerlik makamı 6 Mayıs 1873'te karma komisyonda görev yapmak üzere Vidin kalesi Topçu Kaymakamı Mehmed Said Bey'in tayin edildiğini telgrafla bildirdi. Said Bey'in yanında bölgenin haritasını yapmak ve raporların hazırlanmasında görev almak üzere Erkan-1 Harb Kolağası Veli Bey görevlendirildi. Keza Meclis-i İdareden Osman Bey de görevliler arasindayd $1 .{ }^{54}$

\section{Hazırlanması}

\subsection{Komisyonun Çalışmaları ve Bölgenin Haritasının}

Kaymakam Mehmed Said, Meclis-i İdareden Osman ve Erkan-1 Harb Kolağası Veli Beylerden oluşan komisyon 16 Haziran 1873 tarihinde çalışmalarına başladı. Osmanlı memurları, Sırp hükümeti tarafından görevlendirilen memurlar ile bir araya geldi. Komisyonun görevi ihtilaflı değirmenler ve arazi ile ilgili keşif yaparak sorun hakkında nihai bir karar vermekti. Komisyonun çalışma usulünün tespit edilmesi sırasında Sırp üyeler ilk etapta nehrin kaynak mahalline gitmek üzere görevlendirilmediklerini ifade ettiler. Bunun üzerine durum Bâbıâli'ye

${ }^{51}$ BOA, HR.MKT., 437/32, 24.

${ }^{52}$ BOA, HR.MKT., 775/71, 5.

${ }^{53}$ BOA, HR.SYS., 1393/17, 3-1.

${ }^{54}$ BOA, HR.SYS., 1393/16, 3-1. 


\section{OSMANLI DEVLETI İLE SIRBISSTAN ARASINDA “OYNAK SINIR”: TIMMOK NEHRI'NİN MECRASININ DEĞİŞMESİ VE KARŞILAŞILAN SORUNLAR (1849-1874)}

bildirildi. Yetkililer, Sırp kapıkethüdalığına tebligatta bulunarak memurların kaynak mahalline gitmeleri için talimat verilmesini sağladı. Bilahare Sırp memurları hududun başlangıcı olan Halovo isimli köyden Timok Nehri boyunca Tuna'ya kadar bütün değirmenlerin bendlerini incelemek istediklerini ifade edince mesele farklı bir boyuta taşındı. Osmanlı memurları aldıkları talimat gereği tartışma konusu olan dört adet değirmenden başkasını incelemek hususunda kendilerine müsaade edilmediğini dile getirdi. Müzakereler sürecinde Bâbıâli'den alınan telgrafta Sırp komiserliğinin diğer değirmenler hakkında beyan edecekleri fikir ve değerlendirmelere iştirak edilmeyip yalnız tartışmalı değirmenler hakkında karar verilmesi ve mütalaaların doğrudan Bâbıâli'ye bildirilmesi emredildi. ${ }^{55}$ $\mathrm{Bu}$ şekilde keşifle ilgili temel prensipler tespit edilmiş oldu.

Karma komisyonun çalışmaları sonucunda 12 Ağustos 1873'te Osmanlı adına Erkan-1 Harp Kolağası Veli Bey ve Sırp mühendisi öncelikle Sırp sınırı olarak kabul edilen Timok Nehri'nin Baley köyü topraklarından ayırdığı arazinin haritasını hazırlayıp kopyalarını çıkardı. ${ }^{56}$ Veli Bey, 12 Ağustos 1873 tarihinde Seraskerlik makamına hitaben yazdığı raporda Sırp sınırı olan Timok Nehri üzerinde tartışmalı olan mahallerin tespiti ve düzeltilmesi amaciyla kurulan karma komisyonun çalışmaları sonucunda haritanın hazırlandığını, söz konusu komisyonda gerçekleşen müzakereler sonucunda ortaya çıkan kanaat ve sonucun da rapor olarak hazırlandığını kaydetti.

Veli Bey'in bildirdiğine göre Timok Nehri üzerinde bulunan tartışmalı bölgelerden birincisi Baley köyü civarıydı. Timok Nehri'ne Sırplar tarafından gerçekleştirilen müdahaleler ve bend yapımı sebebiyle nehir eski mecrasını terk ederek Baley köyü önünden akmaya başlamıştı. Bunun sonucunda köy ahalisinin tapulu arazisinden 481 dönümlük (sonuç raporunda 480 dönüm) kısmı Sırp tarafına geçti. Gerçekleştirilen inceleme ve keşiften nehrin mecrasının değişmesinin sebebinin tamamen Sırpların müdahaleleri olduğu anlaşılmıştı. Bununla beraber Sırpların söz konusu yere yeni bir karakol yaparak araziyi haksız yere kendi tasarruflarına almış oldukları da ortaya çıarıldı.

Sadrazamlık makamı söz konusu arazi hakkında detaylı bir inceleme sonucunda kesin bir karar verilip meselenin neticelendirilmesi taraftarıydı.

${ }^{55}$ BOA, HR.SYS., 1393/16, 4-1.

${ }^{56}$ BOA, HR.SYS., 1393/17, 1-1. 


\section{GÜRSOY ŞAHINN}

Ayrıca her iki tarafta kalacak arazilerin bozulmayacak şekilde işaretler konularak muhafaza altına alınması ve neticenin bildirilmesi istendi. Ancak Sırp komisyon memurları söz konusu araziler hakkında kesin karar verilmesine izinleri olmadığını bildirerek yalnızca yapılan keşif ve incelemeleri içeren mazbatadan iki adet düzenleyerek Bâbıâli ve Sirp emaretine takdim edilmesini teklif etti. ${ }^{57}$ Osmanlı komisyonu bu isteğin Sadaret emrine aykırı olduğunu ifade etmişlerse de Sırplar bu hususta 1srarcı oldu. Nihayetinde sadece protokol düzenlenmesine karar verildi.

Erkan-1 Harb Kolağası Veli Bey'in ifadesine göre gerçekleştirilen keşif ve incelemelerin tamamının protokole yazılmasını Sırp komisyon memurları kabul etmedi. Bunun üzerine inceleme sonuçlarının iki tarafın komisyon memurları tarafından ayrı protokollere yazılarak mühürlenmesi teklif edildi. Sırp komisyon memurları yazılacak maddelerin tamamıyla yazılmasına da rıza göstermemiş, bazı maddelerin çıkarılması hususunda 1srarcı olmuşlardı. Bu süreçte düzenlenecek protokole Osmanlı memurları tarafindan yazılması gereken maddeler, gerekli evraklar ve hazırlanan haritanın kopyası Tuna Vilayeti ve Bâbıâli’ye gönderilmiş ve cevap gelene kadar vakit kaybetmemek için Timok Nehri arazisinde tartışma konusu olan dört adet değirmen meselesi de değerlendirilmeye başlanmıştı. Yirmi günden fazla Osmanlı ve Sırp memurları gerekli haritanın suretini çizmekle meşgul oldu. İncelenen dört değirmen hakkında henüz kesin bir karar verilemeden Sırp memurlar nehrin üzerindeki değirmenlerin bendlerinin birbirini etkilediğini ifade ederek bütün değirmenlerin incelenmesi gerektiğini bildirdi. Ancak Osmanlı yetkilileri tartışma konusu olan ve atıl kalmış dört adet ihtilaflı değirmenin incelenmesi gerektiğini diğer değirmenler hakkında herhangi bir problem olmadığını tekrar dile getirdi. Veli Bey'in ifadelerine göre Sırp memurları otuz seneden beri problemsiz işleyen Osmanlı ahalisine ait otuzdan fazla değirmeni tatil etmek ve bununla beraber zikr olunan araziden istifade etmek amacindayd.

Veli Bey'in bildirdiğine göre Sirp tarafinın tavrı sebebiyle hakkaniyet çerçevesinde bir iş görülemeyeceği anlaşılınca söz konusu değirmenler hakkında gerçekleştirilen incelemeleri içeren mazbata ve layiha, Tuna Vilayeti ile Sadaret makamına takdim edildi. Öte yandan Vidin kazasından keşif için memur edilen azalar -muhtemelen zaman kazanmak için- istifa etti, yerlerine de yeni memurlar tayin olunmadi. Bu şartlarda bir netice alınamayacağı anlaşıldı. Ayrıca Sadaretin emrettiğgi Belgradçık

${ }^{57}$ BOA, HR.SYS., 1407/1, 1-1. 


\section{OSMANLI DEVLETI İLE SIRBISSTAN ARASINDA “OYNAK SINIR”: TIMMOK NEHRI'NİN MECRASININ DEĞIŞMESİ VE KARŞILAŞILAN SORUNLAR (1849-1874)}

kazasında ve çit yolunda bulunan kaynak mahallerine gidilemediği de ifade edildi. $^{58}$

\subsection{Komisyonun Hazırladığı Rapor}

Karma komisyon ilk raporunu 16 Ağustos 1873 tarihinde müsvedde olarak hazırladı. ${ }^{59}$ Ancak teşkil edilen komisyonun Sırp memurları raporu imzadan imtina edince taraflar arasında yazışmalar uzadı. ${ }^{60}$ Sonuçta 21 Aralık 1873 tarihinde farklı bir rapor daha hazırlandı. Hazırlanan bu raporda ilk olarak komisyonun kurulma amacı belirtilerek sorun özetlendi. Komisyon memurlarının 18 Haziran 1873 tarihinden itibaren birkaç defa ihtilaflı bölgede buluşarak bahsedilen arazide keşif ve incelemelerde bulunduğu, şahit olunan, tespit edilen hususların bir rapor olarak kaleme alındığ 1 bildirildi. Raporda dört madde ortak olmakla birlikte bunun dışındaki görüş ve değerlendirmeler farklı kaydedildi. Bir başka ifadeyle taraflar ortak bir karara varamadıkları için raporlarda her iki tarafın görüş ve itirazları ayrı ayrı ifade edildi.

Raporun birinci maddesine göre 12 Kasım 1871'de Timok Nehri eski mecrasını terk ederek Baley köyünün önünden ve bölgedeki bir değirmenin harkından akmaya başladı. Komisyon tarafindan çizilen haritadan anlaşılacağı üzere adı geçen köy ahalisine ait araziden beş yüz yetmiş yedi bin yedi yüz yirmi (577.720) metrekare ve dört yüz seksen (480) dönüm genişliğinde arazi Sırbistan tarafinda kaldı.

İkinci maddede ifade edilen husus nehrin eski mecrasına döndürülme çabası ile ilgiliydi. Belgeye göre 1872 yılının Mayıs ayında Baley köyü ahalisi bir bend inşa ederek Timok Nehri'ni eski mecrasına çevirmeye çalışmışlardı. Ancak bu bend derhal Sırp yetkilileri tarafından yıkılmış, yeniden yapılması da engellenmişti. Keza nehrin eski mecrası kıyısında bulunan Sirp karakolu, nehrin yeni mecrasının yakınına yeniden inşa edildi. Ayrıca yine Sırplar, nehrin eski mecrasından akmasını tamamen önlemek için 1872 yılı Ağustos ayında bir bend inşa ederek yukarıda bahs edilen araziyi Sırp topraklarıyla birleştirdi.

\footnotetext{
${ }^{58}$ BOA, HR.SYS., 1407/1, 1-1; Harita ve layihalar 27 Ağustos 1873'de Sadaret makamına arz edilmiş, 3 Aralık 1873 'te karma komisyon tarafindan da tasdik olunmuştur. BOA, HR.SYS., 1393/16, 2-1; BOA, HR.SYS., 1393/17, 3-1.

${ }^{59}$ BOA, HR.MKT., 797/48.

${ }^{60}$ BOA, HR.MKT., 800/98.
} 


\section{GÜRSOY ŞAHIN}

Üçüncü maddeye göre 1872 yılının başlarında Sırp ahalisinden Dimitri Milodonivin ve İstipolçe İzdiravkovin adlı kişiler Osmanlı arazisini almak için teklifte bulunmuşlardı. Dimitri ve İstipolçe, Berkofçalı Yuvan Nakro, Kobišnicalı Kristo İstakonob ve Yinkotin isimli kişilere 2.400 Nemçe altını karşılığında arazilerini satmayı teklif etmiş ve pay olarak da 20 adet Nemçe altını vermişlerdi. Ancak iki taraf hükümetlerinin buna rıza göstermemesi ve olur vermemesi ile araziyi satın almak amacıyla verdikleri paylar kendilerine iade edildi ve teklifleri reddedildi.

Dördüncü maddeye göre 1873 yılında bahsi geçen arazi üzerinde yetişen otları biçtirmek üzere iki taraftan birer görevli seçilmişti. Baley köyü ahalisi ile Sırplar beraberce otları biçmişlerdi. Otların yarısı çalışanların yevmiyesine ayrılmış, kalanı açık artırma usulüyle 50,5 (elli buçuk) Nemçe altını bedelle ahaliye satılmıştı. Otların satışından elde edilen meblağ hak elde edecek tarafa verilmek üzere Vidin hükümet sandığında muhafazaya alınd $1 .{ }^{61}$

$\mathrm{Bu}$ dört madde mesele ile ilgili yaşanan gelişmeleri aktarmaktaydı. Raporun geri kalan kısmında Osmanlı ve Sırp tarafının meseleye bakışını ortaya koyan görüşler ayrı ayrı sunulmaktaydı. Taraflar bu konuda uzlaşma sağlayamadı ve nehrin yatağını değiştirmesi hususunda her iki taraf da kendi görüşünü savundu. Rapordan anlaşılacağı üzere sınırla ilgili Sırp tarafının birden fazla eylemi bulunmaktaydı. Sırplar nehrin yatağını değiştirmekle kalmamış aynı zamanda nehrin eski yatağına dönmesini engellemek için bend inşa etmişlerdi. Üstelik bir de karakol inşa edilerek tamamen fiziki şartlar sebebiyle Sırp tarafina geçen araziyi bir oldu bitti ile Sırp topraklarına katmak için sistematik bir çaba göstermişlerdi.

\subsection{Osmanlı ve Sırp Komiserlerinin Değerlendirme ve İtirazları}

İlk olarak Osmanlı komiserleri konuyla ilgili görüşlerini rapora kaydetti. Sırp yetkililerin iddiasına göre Timok Nehri’nin eski mecrasının değişmesinin sebebi Baley köyü ahalisinin 1859-1860 (H.1276) senesinde köyün önündeki araziye bir adet değirmen inşa etmeleri ve bu değirmenin çalışmasına yetecek kadar su akıtmak için bir hark açmalarıydı. İddiaya göre değirmen Timok Nehri'nin taşması sonucu tamamen harab oldu. Ayrica bahsedilen arazi nehrin öte tarafinda kaldı. Aradan bir sene geçtikten sonra değirmenin yeri değiştirilerek haritada özel işaretle gösterilen mevkide

${ }^{61}$ BOA, HR.MKT., 797/48; BOA, HR.SYS., 1393/17, 7-1. 


\section{OSMANLI DEVLETI İLE SIRBISSTAN ARASINDA “OYNAK SINIR”: TIMMOK NEHRI'NİN MECRASININ DEĞIŞMESİ VE KARŞILAŞILAN SORUNLAR (1849-1874)}

yeniden inşa edildi. Türk tarafı buna itiraz etmekteydi. Zira Osmanlı komiserine göre nehrin yatak değiştirmesinin sebebi Sırp ahalisinden Yuvan $^{62}$ İstifanoyik ile ortaği tarafindan 1865-1866 (H.1282) senesinde haritada işaret olunan yerde bir adet değirmenin inşa edilmesiydi. $\mathrm{Bu}$ değirmenin bendi zaman içerisinde nehrin eski mecrasının dolmasına sebep oldu. Hazırlanan haritadan da nehrin eski mecrasında bahsedilen değirmenin üst tarafından başlayarak Timok Nehri'nin mecrasının değiştiği yere kadar kum ile ve alt tarafının da su ile dolduğu anlaşılmaktaydı. Bu suretle Timok Nehri, doğal olarak mecrasını değiştirmeye meyletti. Sonuç olarak nehrin suyunun üçte birlik kısmı nehir yatağından ve üçte ikilik kısmı da Baley köyü değirmeninin harkından akmaya başladı. Bunun üzerine Baley köyü ahalisi meşru haklarını korumak niyet ve maksadıyla kendi değirmenleri harkının başında bir bend inşa etmeye girişti. Ancak Sırp yetkililer tarafindan bu bend yıkılarak tekrar yapımına engel olundu. Ardından Sirplar nehrin eski mecrasına on beş metre genişlikte bir sed yaptı. Böylece Timok Nehri'nin suları tamamen Baley köyü değirmeni harkından akmaya başladı. Sonuç olarak bölgedeki arazi, arsa, ev ve sair yerler tamamen Sirp toprakları tarafında kaldığ 1 gibi Baley köyü değirmeni ile Sırp tarafındaki değirmenin harap ve atıl durumda kalmasina sebep olundu.

Sırp komiserlerine göre nehrin mecrasının değişmesi Baley köyü ahalisinin inşa ettikleri değirmenin bendinden kaynaklanmaktaydı. İfadelere göre Timok Nehri'nin mecrasını değiştirmesi değirmeninin bendinin haritada gösterildiği gibi yüksek olması ve harkın da eski mecrada açılmasıydı. 1871 senesi kış mevsiminde aşırı yağışlar sonucu nehir taşmış, sular da doğal olarak Baley köyünün değirmeni harkına doğru meyletmişti. Sirp komiserlere göre benzer şekilde 1848-1849 (H.1265) senesi ilkbahar aylarında ekte takdim olunan ${ }^{63}$ bir adet küçük haritadan anlaşılacağı üzere nehir eski mecrasını terk edip Baley köyü değirmeni harkına doğru akmaya başlamıştı. Komiserlerin ifadelerine göre kısa yol ve akıntı ortaya çıkması ile başlayan yatak değişikliği Baley köyü ahalisinin nehre bend yapması üzerine engellenmişti. Sırp görüşüne göre şayet bu olmasaydı daha o vakit nehrin mecrası değişmiş olacaktı. ${ }^{64}$

Baley köyü ahalisi 1872 senesinde meydana gelen taşkın ve nehrin yatak değiştirmesi üzerine yine bir takım teşebbüslerle Timok Nehri'ni eski

\footnotetext{
${ }^{62}$ Harita üzerinde ve Sırp tarafının değerlendirmelerinde "Danilo" olarak kaydedilmiştir.

${ }^{63}$ Belge eklerinde bu harita mevcut değildir.

${ }^{64}$ BOA, HR.SYS., 1393/17, 7-1.
} 


\section{GÜRSOY ŞAHIN}

mecrasından akıtmaya kalkışmışlar ise de bu durum Sırplar tarafından engellenmişti. Danilo İstifanoyik ve ortaklarının değirmeni, haritada gösterildiği üzere bahsedilen mevki ve mahallin uzağındaydı. Keza Baley köyü değirmeni bendinden aşağıda bulunması nedeniyle mecra değişimine sebep olması mümkün görünmemekteydi. Sırp komisyonu, Osmanlı komiserlerinin suyun üçte ikilik kısmı Baley köyü önünden ve üçte birlik kısmı eski mecradan aktığı şeklinde 1srar etmelerine bir mana veremediklerini bildirdi. Sırp komiserlere göre bir nehrin suyu hangi tarafa daha fazla meyil eder ve oradan akarsa o tarafi nehri kabul etmek lazımdı.

Osmanlı komiserleri, konuyla ilgili Sırp komiserlerinin iddialarına itirazda bulundu. Sirp komiserleri tarafindan bahsedilen ve Timok Nehri'nin 1865 yılında Baley köyü önünden aktığını gösteren haritadan o vakitlerde nehrin köy değirmeni harkından şiddetli bir şekilde aktığı anlaşılmaktaydı. Ancak nehrin 1871 senesine gelinceye kadar eski mecrasını terk ettiği veya değiştirdiğinin örneğinin bulunmadığ 1 kaydedildi. Bu durum gerçekleştirilen incelemeler sonucunda anlaşılmış, civardaki köy ahalisi de aynı durumu teyit etmişti.

Osmanlı komiserleri, Sırp komiserlerinin iddia ettiği gibi nehrin 1865 'te mecrasını değiştirdiği ve köy ahalisinin de birtakım uğraşlarla suyu eski yatağına çevirdikleri iddiasını kabul etmemekteydi. Keza değirmen bendinin nehrin yatağını değiştirmesinin mümkün olmadığı da ifade edilmekteydi. Bu durum gerek o sirada ihtilaflı olan diğer değirmenlerin keşfi için bölgeye gelen memurların gerekse Baley ve Bregovo köyü ahalisinin ifadelerinden teyit edilmişti. Sonuç olarak Timok Nehri mecrasını sebepsiz olarak değiştirmiş olsa bile Sırpların eski mecra üzerine bend inşa etmesi ve yeni mecra kenarına yani Baley köyü arazisine yeni bir karakol inşa etmesi hakkaniyet kaidesine uymamaktaydı.

Türk tarafının değerlendirmelerine karşılık Sırp komiserleri de bazı itirazlarda bulundu. Sirp komiserlere göre 1865 senesinde Timok Nehri eski mecrasını terk edip Baley köyü değirmeni harkından akmaya başlamıştı. Bunun üzerine köy ahalisi derhal müdahale ederek bir takım işlemler sonucunda suyu yine eski mecrasına döndürmeyi başarmış, dolayısıyla problemle ilgili Osmanlı hükümetine müracaata lüzum görülmemişti. ${ }^{65}$ Danilo İstifanoyik isimli Sırpın değirmeninin bendi ile nehrin eski mecrası üzerinde inşa olunan bendin Timok Nehri'nin tamamen eski mecradan

${ }^{65}$ BOA, HR.SYS., 1393/17, 7-2. 


\section{OSMANLI DEVLETI İLE SIRBISSTAN ARASINDA “OYNAK SINIR”: TIMMOK NEHRI'NİN MECRASININ DEĞİŞMESİ VE KARŞILAŞILAN SORUNLAR (1849-1874)}

akmasına mani olduğu şeklindeki Osmanlı komiserlerinin değerlendirmeleri de kabul edilmemekteydi.

Sirp karakolunun eski yerinden Baley köyü arazisi üzerine nakli konusunda bilgi veren komiserlere göre nehrin mecrasının değişmesinden dolayı söz konusu arazi Sırp tarafına geçti. Dolayısıyla yapılan işlem sınırın korunması esasına uygundu. Keza bahsedilen arazi hakkında iki taraf hükümeti arasında karar verilip sınır tespit edilinceye kadar etrafına çit çekilmeyerek bölge geçici sınır olarak kabul edildi.

Sırp komiserler, Bregovo köyündeki Sırp arazisi hakkında Osmanlı komiserleri tarafindan dile getirilen hususlar hakkında da değerlendirmeler yapt1. Buna göre söz konusu arazideki durum Baley köyü arazisine asla benzememekteydi. Verilen bilgilere göre 1833 y1lında Bregovo köyü yakınında, Timok Nehri sahilinde Hacı Abdullah isimli bir kişinin bir miktar arazisi ve bir adet değirmeni bulunmaktaydı. Söz konusu bölge, Padişahın Sırplara tanıdığı imtiyaz gereği Sırp toprakları tarafında kalmıştı. Daha sonra zikr olunan değirmenin bendi suyun akışına engel olduğu için Timok Nehri mecrasını değiştirmiş ve bahs olunan arazi Türk tarafına geçmişti. Ancak 1834 yılında Vidin valisi olan merhum Ağa Hüseyin Paşa tarafından müteveffa Miloş Bey'e ihsan buyrulan bir kıta nişanı teslim etmek üzere bahsi geçen bölgede gerçekleşen mülakatlarında nehrin yatak değiştirmesinden dolayı Türk tarafına geçen arazinin yine Sırpların tasarrufu altında kalması kararlaştırıldı. Keza arazi üzerinde Sırplar tarafından yeniden bir karakol inşa olunması da kabul edildi.

Sırp yetkililere göre kırk seneden beri Sirpların tasarrufunda olan söz konusu Bregovo arazisi, 1872 yılında yaşanan problem ve arazi değişmesine emsal tutulamazdı. Sırplara göre son durum olsa olsa bundan birkaç sene önce Drina Nehri'nin mecrasını değiştirmesinden dolayı Sırpların o civarda tasarrufları altında olan ancak Türk tarafına geçmiş olan bir hayli miktar arazinin benzeri olabilirdi. ${ }^{66}$

Osmanlı komiserleri, Sırp komiserlerin itirazlarına karşı tekrar itirazlarını dile getirdi. Sırp komiserleri, görevlerinin yalnız bölgede keşif yaparak şahitlik ve incelemelerinin sonucunu ortak bir mazbatada kaleme almaktan ibaret olduğunu, bu hususta Bâbıâli ile Sırp yetkililer arasında karar verileceğini beyan etti. Osmanlı komiserleri ise son olarak Baley köyü

${ }^{66}$ BOA, HR.SYS., 1393/17, 7-3. 


\section{GÜRSOY ŞAHIN}

ahalisinin hukukunun çiğnemesine ve müdahale edilmesine asla izin verilemeyeceğini, bahsolunan karakolun eski mahalline nakli ve nehrin de eski yatağına döndürülmesi gerektiğini tekrar vurguladı.

Sırp komiserleri, mazbatanın sonunda keşfi yapılan arazi ile ilgili kesin bir karar verilmesine izinleri olmadığını tekrarladı. Diğer taraftan sorunun Drina Nehri'ndeki arazi meselesine emsal tutulması gerektiği ve konunun Bâbıâli ile Sırp emareti arasında çözülebileceğini ifade etti. ${ }^{67}$

\subsection{Komisyonun Değirmen Bendleri Hakkındaki Raporu ve Tarafların Görüşleri}

Osmanlı ve Sırp yetkililerinden oluşan komisyon, bölgedeki değirmenlerle ilgili yaptıkları keşif ve incelemelerini 21 Aralık 1873 tarihinde bir rapor haline getirmişlerdi. Raporda, Timok Nehri üzerinde bulunan dört adet dolap değirmeni nedeniyle Osmanlı ve Sirp ahalisi arasındaki ihtilafın üç yıldır devam ettiği ifade edilmekteydi. Sorunun, milletlerarası hukuk ve şahsiye kaidesine uygun olarak halledilmesi ve bir neticeye bağlanması amaciyla kurulan karma komisyonun 16 Temmuz 1873 'ten itibaren birkaç defa toplandığı, bölgede gerekli keşifleri yaptığı ve bölgenin haritasını hazırladığı vurgulandı.

Değirmenlerle ilgili hazırlanan keşif raporuna göre tartışma konusu olan değirmenlerin birincisi Türk tarafinda ve Kokomadka denilen mevkide Baley köyünden İstanko Yuvan, Korkenasb ve diğer ortaklarının değirmeniydi. İkinci değirmen bunun üst kısmında ve Sirp tarafında Kobišnica köyünden Yuvan Markoğ ve Petro Povandiç isimli Sırplara aitti. Üçüncüsü yine Türk tarafında Viros denilen mahalde Bregovo köyünden Yanko Vladimitro, Reşov Yanko ve diğer ortaklarının değirmeniydi. Dördüncüsü Yanko Vladimitro ve ortaklarının değirmeninin üst tarafında Muslariçe denilen yerdeydi. Bu değirmenin sahipleri Bregovo köyünden Pize Baloça, İstanko Baloça ile diğer ortaklardı. Ayrıca bu değirmenin karşısında Sırp tarafında Kobišnica'ya karşı İstifanoyuk ve ortağının sahip oldukları bir diğer değirmen mevcuttu. Karşılıklı kurulmuş bu değirmenler ortak bir bend ile çalışmaktaydı. Bunlardan yalnız üçüncüsü yani Viros değirmeni çalışmakta olup diğer değirmenler atıl vaziyetteydi.

\footnotetext{
${ }^{67}$ Mazbata 21 Aralık 1873 tarihinde Türkçe ve Sırpça olarak iki nüsha halinde düzenlenmiş, üç Osmanlı ve üç Sırp komiseri tarafından imza edilmiş ve birer nüshası taraflarda kalmıştır. BOA, HR.SYS., 1393/17, 7-3.
} 


\section{OSMANLI DEVLETI İLE SIRBISSTAN ARASINDA “OYNAK SINIR”: TIMMOK NEHRI'NİN MECRASININ DEĞIŞMESİ VE KARŞILAŞILAN SORUNLAR (1849-1874)}

Karma komisyonun tespitlerine göre söz konusu değirmenlerin bendlerinin yüksekliği $60 \mathrm{~cm}$ ve daha aşağı olması halinde birbirlerine ve iki tarafın arazisine zarar vermeyecek şekilde işleyebilecekti. Böylece bölgedeki bütün değirmenlerin bendinin, olukları başından itibaren $60 \mathrm{~cm}$ yüksekliğinde yapılması kararlaştıııldı. Şayet $60 \mathrm{~cm}$ 'den yüksek bend yapılır ve bundan dolayı herhangi bir taşkın ve zarar ortaya çıkarsa hangi tarafın bu duruma sebep olduğunu tespit edebilmek ve bendin yüksekliğini ölçebilmek için her değirmen bendine has biri Türk diğeri de Sırp tarafına işaret olarak birer kazık dikilmesi kararlaştırıldı. Bu esaslar çerçevesinde bütün değirmen bendlerinin kararlaştırılan ölçüden daha yüksek olduğu görülmüştü.

Yeni belirlenen değirmen bendi ölçüsüne göre bazı kararlar alındı. Buna göre;

1-Muslariçe isimli yerdeki çifte değirmenlerin bendinin ne yükseklikte olacağını göstermek için nehrin Türk tarafına çakılan kazığın başından Sırp tarafindaki kazığın üst tarafına doğru ortak bir bend yapılacaktı. Eski bend yıkılıp temizlenecek, su da yarı yarıya değirmenlere paylaştırılacaktı. ${ }^{68}$

2-Sorunlu değirmenlerin bendindeki kazıklar, bend yüksekliğini aşmayıp bir hizada olacaktı. Bu suretle yapılacak bendlerin üst tarafından beşer ve alt tarafından onar metre uzunluğunda kazıklar çakılarak aralarına çalı konulacak ve kıyılar sağlamlaştırılacaktı.

3-Söz konusu bendlerin kurallara uygun yapılması ve öylece kalmasına özelikle dikkat edilecek ve bendlerin zarar görmesi halinde vakit müsait olursa derhal tamiratı gerçekleştirilecekti. Eğer vakit müsait olmayıp tamir olunamazsa iki taraf hükümeti haberleşerek zarar görmüş bendi, nehrin kıyılarının harap olmasını engellemek için tamamen kaldırtacak fakat değirmenin sahibi istediği vakit yeniden bend yapıp değirmenini işletme hak ve yetkisine sahip olacaktı.

4-Nehre özel işaret olarak çakılan kazıklar özelliklerini kaybetmeye başladığında değirmen sahipleri kendi ülkelerinin hükümet yetkililerine haber verecek ve iki taraf hükümetleri haberleşerek tayin edecekleri memurlar marifetiyle işaret kazıklarını yeniden yerine çaktıracaktı.

${ }^{68}$ BOA, HR.SYS., 1393/17, 6-1. 


\section{GÜRSOY ŞAHIN}

5-İki tarafın değirmen sahiplerine kararlaştırılan hususlara uymaları ve gereğini yapmaları konusunda gerekli uyarılarda bulunulacaktı. Söz konusu tenbihten sonra şayet değirmencilerden herhangi birisi kararın aksine hareket ederek diğerine zarar verecek olursa keşif yapıldıktan sonra, zarar ve ziyana sebebiyet veren taraf itiraz etmeksizin gerekli ödemeyi yapmaya mecbur olacakt1.

Komisyonların değirmen bendleriyle ilgili hazırladıkları raporlarda yukarıda ifade edilen beş madde belirtildikten sonra tarafların görüşlerine yer verildi. Mevcut sorunun geçmişi ile ilgili bilgiler verilerek hem Sırp hem de Osmanlı komiserlerinin görüşleri rapora ayrı ayrı kaydedildi.

Raporda ilk olarak Sirp komiserlerinin ifadeleri yer almaktaydı. Sirp komiserler, komisyonun Timok Nehri üzerinde ve iki taraf ahalisinin tasarrufu altında olan değirmenlerin bendlerinin birbirlerine zarar vermeyecek yükseklikte eşitlenmesi için kurulduğunu hatırlattı. ${ }^{69}$ Problemin geçmişi hakkında bilgi veren Sırp yetkililer, Osmanlı komiserlerinin kendilerine verilen talimata göre sadece tartışmalı olan dört adet değirmenin keşfine memur olduklarını, ancak kendilerinin nehir boyundaki tüm değirmenlerin incelenmesi ve bendlerinin düzeltilmesi talebinde bulunduklarını belirtti. Ancak Bâbıâli buna izin vermeyince öncelikle tartışmalı değirmenlerle ilgili herkes tarafından kabul edilecek bir karar verilmesi, diğer değirmenler hakkındaki görüş ve düşüncelerin ise düzenlenecek rapora eklenmesinin uygun olacağı bildirildi. Bu sebeple Sirp memurlar toplam on adet değirmenle ilgili görüşlerini hazırlanan rapora kaydetti.

Sirp komiserlerinin belirttikleri birinci husus nehir üzerinde ve Türk tarafinda bulunan Rakobiçe köyündeki bir adet değirmenin bendinin yüksekliğinin $91 \mathrm{~cm} 2 \mathrm{~mm}$ olduğuydu. Yine Türk tarafında lane tabir olunan bir adet değirmenin bendi $132 \mathrm{~cm}$ yükseklikteydi. Türk tarafında bir diğer değirmenin bendinin $160 \mathrm{~cm}$ yükseklikte olduğu bildirildi. Ayrıca İzlakok köyü yakınında Vavraşe denilen mahalde Nikola Yanok ve Crnomasnica köyünden Dimitro Trallivan isimli kişilerin bir adet değirmen bendi $137 \mathrm{~cm}$ idi. Crnomasnica köyü yakınında Mitardino, Rado Birov ve diğer ortakların işlettikleri bir başka değirmenin bendi ise $106 \mathrm{~cm}$ idi.

${ }^{69}$ BOA, HR.SYS., 1393/17, 6-1. 
OSMANLI DEVLETİ İLE SIRBISSTAN ARASINDA “OYNAK SINIR": TIMMOK NEHRI'NİN MECRASININ DEĞIŞMESİ VE KARŞILAŞILAN SORUNLAR (1849-1874)

Sırp komiserlerin dile getirdikleri diğer husus Banofça köyü yakınında Dokaşin ve Petro Miloyivik isimli ortakların sahip oldukları değirmenin bendinin $82 \mathrm{~cm}$ yükseklikte olduğuydu. Komisyon üyelerinin belirttiği bir başka husus Sırp karakolu yakınında ve Türk tarafındaki Graçko köyünden Toşko Buradin ve ortaklarının değirmeni ile yine aynı bölgede ancak Sırp tarafında Zaječar kazasına bağlı Rajogarince köyünden Avron Miloşevik isimli Sırpın sahip oldukları karaca değirmenin bendleriyle ilgiliydi. Bu değirmenlerin ikisinin bendi de nehrin suyunun yarısı ile çalıştırılmak üzere ortaklaşa inşa olunmuştu. Komiserlerin iddialarına göre Türk tarafındaki bend muntazam olmayan bir şekilde inşa edilmişti. ${ }^{70}$ Zaječar kazasına bağlı Ternoviçe köyü civarında Türk tarafında Hacı Nuri Ağa'nın sahip olduğu ve sürekli olarak işlemekte olan bir diğer değirmenin bendi $111 \mathrm{~cm}$ idi. Bu sebepten Sırp tarafında Avron Miloşevik isimli Sırpın değirmeninin işlemeyip atıl kaldığı görülmüştü. ${ }^{71}$

Komiserlerin dile getirdiği diğer husus Türk tarafındaki ahalinin Timok Nehri yakınında sahip oldukları karaca olarak adlandırılan üç adet değirmen ile ilgiliydi. Değirmenciler, değirmenlerine belirli bir seviyede su akması için nehrin içerisini bir takım taşlarla doldurmuşlardı. Nehir içerisine atılan taşlar vasitasıyla sular oluklara taksim olunarak akmaktaydı. Öte yandan nehrin içerisine taşların doldurulması, aşırı yağmur yağdığında suyun akmasına engel olmakta ve nehrin taşmasına sebep olmaktaydı. Son olarak Sırpların Balaberişka karakolu civarında ve Türk tarafında bir adet değirmenin bendi de muntazam değildi.

Sırp yetkililerin ifadelerine göre yapılan keşifler sonucunda Türk tarafındaki değirmenlerin birçoğunun bendleri düzensiz olup tüm değirmenlerin bendinin $60 \mathrm{~cm}$ 'ye indirilmesi gerekmekteydi. Sadece dört adet değirmenin bendlerinin seviyesinin eşitlenip, etrafında bulunan arazinin kurtarılması buna karşılık diğer değirmenlerin düzensiz bırakılması doğru olmayacaktı. Şayet tüm değirmenlerin bendleri nizami bir şekilde yapılmazsa nehrin taşması halinde Sırplara ait hayli miktar arazi Türk tarafına geçecekti. Ayrıca komiserlerin bildirdiğine göre suların etrafa dağılması civardaki Sırp ahalisinin arazisini harap etmekteydi. Bu duruma sebep olmamak için suların akışına engel olan nehir içerisindeki taşlar ile bendleri düzensiz inşa edilmiş değirmenlerin bulunduğu yerden tamamen

${ }^{70}$ BOA, HR.SYS., 1393/17, 6-2.

${ }^{71}$ BOA, HR.SYS., 1393/17, 6-2. 


\section{GÜRSOY ŞAHIN}

kaldırılması ve nehrin Türk tarafına yakın bulunan değirmenin de yerinin değiştirilmesi gerekli görülmüştü.

Sırp komiserler, Timok Nehri kenarında bulunan değirmenlerin istisnasız tamamının Osmanlı ve Sırp hükümetleri aralarında anlaşıp belirli bir nizama alınıncaya kadar Sırp hükümetinin nehir kenarında sakin olan ahalinin sahip oldukları değirmen ve arazinin zarar ve ziyandan korunması hususunda gerekli teşebbüste bulunma hakkının olduğunu da vurguladı. Ayrıca Türk tarafında bulunan değirmenlerin sayısal olarak fazlalığından dolayı Sırp ahalisinin de istediği vakit tek başına değirmen inşa edebilmesinin hakkaniyetin gereği olduğundan bahsedildi. Keza değirmen yapımı konusunda gerek bundan önce verilen ve gerekse bundan sonra verilecek olan dilekçelerin kabul edilerek ruhsat verilmesinin lazım geleceği dile getirildi. ${ }^{72}$

Osmanlı komiserleri, tartışma konusu olan ve bend yükseklikleri hakkında karar verilen dört adet değirmenden başka bir husus hakkında görüş bildirmeye yetkili olmadıklarını ifade ettiler. Sonuçta hazırlanan raporun bir nüshası Türkçe ve diğer nüshası Sırpça olarak düzenlenerek iki tarafının üçer kişiden oluşturduğu komisyon üyelerinin imzası, mühürleri ve şerhleriyle birlikte karşı tarafa verildi. ${ }^{73}$

\subsection{Osmanlı Komiserlerinin Sonuç Raporu}

Sırp komiserlerinin tüm itiraz ve değerlendirmelerini dikkate alarak Osmanlı komiserlerinin kaleme aldıkları 27 Aralık 1873 tarihli son rapor daha kapsayıcı bir içeriğe sahipti. Söz konusu rapor, gerçekleştirilen keşif ve incelemeler sonucunda Topçu Kaymakam Mehmed Said, Meclis-i İdareden Osman ve Erkan-1 Harb Kolağası Veli Beyler tarafından kaleme alındı. Vidin mutasarrıflığına hitaben yazılan raporda sorunun geçmişi özetlendi. Buna göre Timok Nehri'nin Osmanl1-Sırp sınırı olarak kabul edildiği, Sırpların 1872 yılında nehre bir bend inşa edilerek suyun akış yönünün Baley köyünün hemen önüne çevrildiği bildirildi. Bunun üzerine nehrin eski mecrasında kalan Baley köyü arazisi, nehir civarında bulunan dört adet değirmen bendi, Belgradçık kazasında bulunan Vilaçoviç Balkanı ile sınırın 107 metre yakınında bulunan ve Sırplar tarafindan kendi sınırlarına dahil edilen araziler hususunda tartışma çıktığı hatırlatıldı. Bu sorunları çözmek

${ }^{72}$ BOA, HR.SYS., 1393/17, 6-3.

${ }^{73}$ BOA, HR.SYS., 1393/17, 6-3. 


\section{OSMANLI DEVLETI İLE SIRBISSTAN ARASINDA “OYNAK SINIR”: TIMMOK NEHRI'NİN MECRASININ DEĞIŞMESİ VE KARŞILAŞILAN SORUNLAR (1849-1874)}

üzere Osmanlı ve Sırp yetkililerinden oluşturulan karma komisyonun çalışmalarına başladığı vurgulandı.

Raporun birinci maddesine göre Vidin kazasına bağlı Berkofça-i Sağir köyü ahalisinden birkaç kişinin Timok Nehri üzerinde ve Türk tarafında bulunan değirmen bendlerinin bir miktar yüksek olduğu anlaşılmıştı. Ancak Osmanlı komiserleri, Sırp komiserlerinin iddialarındaki gibi değirmen bendinin nehrin taşkını sırasında suların akmasına engel olmadığını ifade etmekteydi. Öte yandan nehrin taşmasına sebep olduğu ifade edilen söz konusu değirmenin üst tarafinda, yarım saat mesafede bulunan Sirplara ait değirmenin bendinin nehrin ilerisine doğru sokulduğu görülmüştü. Bu durumun hem bahsi geçen iki adet değirmenin çarklarının dönmesine ve hem de Timok Nehri'ndeki suların akışına mani olduğu, bu sebeple suyun doğal olarak farklı taraflara dağılacağı belirtildi. Keza incelenen değirmenlerden bir kısmının çalışmadığı da görüldü. Söz konusu değirmen bendi $30 \mathrm{~cm}$ kadar aşağı indirilmiş olsa bile nehrin taşmasını engellemeyeceği anlaşıldı. Hülasa Türk tarafının görüşüne göre taşkın, değirmenlerin bendlerinin yüksekliğinden kaynaklanmamaktaydı.

Raporun ikinci maddesine göre Vidin ve Adliye kazalarına bağlı Bregovo ve İzlakok köyleri ahalisinden birkaç kişinin nehir üzerinde sahip oldukları üç adet değirmenin bendlerinin kazıkları Sırp komiserlerinin daha önceki raporlarda vurguladığı gibi $60 \mathrm{~cm}$ yükseklikteydi. Ancak buna rağmen Sırpların nehir kıyısındaki arazilerinin iki üç metre ve Osmanlı tarafındaki arazinin kıyılarının ise daha fazla zarar gördüğü tespit edilmişti. Keza Türk tarafinda Karyotore denilen yerdeki değirmeninin üst tarafında ve Sırp tarafinda bir kişinin değirmeni hark ve bendinin olması gerektiğinden yüksek olduğu görülmüştü. Bu yüzden adı geçen değirmen bendlerinin alçaltılması gerektiği bildirildi.

Raporun üçüncü maddesi Adliye kazasına bağlı Crnomasnica köyü civarında bulunan Mitardino isimli kişiyle ortaklarının sahip oldukları değirmen bendiyle ilgiliydi. Bu değirmenin bendi $60 \mathrm{~cm}$ yükseklikteydi. Ancak Sırp komiserlerin ifade ettikleri mahzur, bendin yüksekliğinden daha ziyade nehrin tabi akışından kaynaklanmaktaydı. Nehirden değirmen bendine doğru giden derede suyun çok az kısmının aktığı, bazı seneler aşırı yağmurlar sebebiyle tehlike arz edeceği tespit edilmişti. Bu durumda Sirp komiserlerinin dile getirdikleri iddialar üzerinden hareket edilirse değirmenin sahibinin ciddi bir masrafa gireceği ayrıca değirmenin tamamen 


\section{GÜRSOY ŞAHINN}

atıl kalacağı kaydedildi. Bu durumun ise değirmen sahibine zulüm olacağ1 bildirildi.

Raporun dördüncü maddesi Adliye kazasına bağlı Banofça köyü yakınında bulunan Vekasin ve Mitrosilovi isimli kişilerin sahip oldukları değirmenin bendi hakkındaydı. $\mathrm{Bu}$ bend de Sırp komiserliğinin üzerinde özellikle durduğu şekilde yani $60 \mathrm{~cm}$ yükseklikteydi. Raporda nehrin kıyılarında bir iki metre mesafede yaşanan harabiyetin sebebinin bendin yüksekliğine bağlı olmadığı, nehrin tabi akışından kaynaklandığı kaydedilmekteydi. $^{74}$

Beşinci madde Adliye kazasına bağlı Graçko köyü yakınında, Timok Nehri üzerinde Toşko Buradin ve ortaklarının sahip oldukları değirmen hakkındaydı. Bu değirmen iki taşlı dolap değirmeni olup bunun karşısında Sırp tarafında Avron Miloşevik isimli Sırpın altı taşlı kuca olarak ifade edilen bir değirmeni vard1. A. Miloşevik ve ortakları değirmenlerinin bendini tamamen kâgir inşa etmeye niyetlenmişlerdi. Bu suretle suyun büyük çoğunluğunu kendi değirmenlerine alarak Osmanlı tarafındaki değirmeni bilahare atıl bırakmak maksadına yöneldikleri öngörülmüştü. Komisyon, Osmanlı yetkililerine Sırp tarafındaki değirmenin sahibinin izin talebine bu durumu göz önünde bulundurarak cevap verilmesi önerisinde bulundu. Ayrica bendin altından suyun sızmasının bendin harabiyetine sebep olacağı, bendin inşa veya tamirinde gerekli usullere uyulması konusunda tenbihatta bulunulmasi tavsiye edildi.

Raporun altıncı maddesinde Graçko köyü sınırı içinde Hacı Nuri Ağa'nın sahip olduğu değirmenin zemininden bahsedilmekteydi. Söz konusu değirmen uçurumun kenarında olduğu için bendi yok denecek kadar azdı. Bu değirmenin karşısında Sırp tarafında Avron Miloşevik isimli Sırpın bundan dört sene önce kurmuş olduğu değirmenin mevkisinin de yokuş ve uygunsuz olmasından dolayı işlemediği anlaşılmıştı. Hacı Nuri Ağa'ya ait değirmenin bendinin $111 \mathrm{~cm}$ yüksekliğinde olduğu, değirmenini yeniden inşa edecek Avron Miloşevik' in değirmen bendinin inşasına Nuri Ağa'nın engel olunduğu Sırp komiserleri tarafindan ifade edilmişti. Raporda bildirildiğine göre Hacı Nuri Ağa'nın değirmeni karşısında yeniden bir değirmen kurmak için taş tedarik eden Avron Miloşevik'in adı geçen kişi ile uzlaşmaları halinde değirmen inşasında herhangi bir mahzur bulunmadığı bildirildi.

${ }^{74}$ BOA, HR.SYS., 1393/16, 4-1. 


\section{OSMANLI DEVLETI İLE SIRBISSTAN ARASINDA “OYNAK SINIR”: TIMMOK NEHRI'NİN MECRASININ DEĞIŞMESİ VE KARŞILAŞILAN SORUNLAR (1849-1874)}

Yedinci madde Adliye kazasına bağlı Halovo köyü ahalisinden birkaç kişinin Orina Kobila olarak bilinen mevkide sahip oldukları üç adet karaca değirmen hakkındaydı. Bir dağ eteğinde ve Timok Nehri’nin Türk tarafında tapulu mülk olan bu değirmenin inşa tarihinin 1842 yılına kadar gittiği ve suyun alçak bir oluk marifetiyle şimdiye kadar hep oradan aktığı inceleme sonucunda anlaşılmıştı. Surp komiserlerinin bu değirmenin bendleri hakkındaki iddialarının asılsız olduğu, Sırp arazisinin bu değirmenlere epeyce mesafede bulunduğu bildirildi. Keza söz konusu değirmenlerin harklarındaki ufak taşların nehrin akışına engel oluşturmadığı, suyun akışına ancak iki taraftaki dağların altındaki büyük kayaların mani olabileceği ihtimal dairesinde görüldü. $\mathrm{Bu}$ şartlarda bahsedilen değirmenlerin Sırp arazisini ayırmak gibi bir ihtimalinin bulunmadığ $\breve{1}$, Sırp komiserlerinin iddiaları üzerine mezkur değirmenlerin kaldırmasının ancak sahiplerine zulüm olacağı değerlendirmesi yapıldı. ${ }^{75}$

Raporun sekizinci maddesi Sırpların Balaberişka karakolu civarında ve Türk tarafında bulunan değirmen ile ilgiliydi. Sirp komiserlerinin yukarıda bahsettikleri değirmenin önünde esasen bütünüyle bir ada bulunduğu, bu sebeple bu değirmenin de Sırp arazisinin kıyılarında herhangi bir harabiyete sebep olmayacağ 1 ifade edilmekteydi. Keza değirmen sahibi tarafından da bendin intizamlı bir şekilde tamir ve inşa edileceği bildirildi.

Yapılan incelemelerde Türk tarafında bulunan değirmenlerden dörtbeş adedinin bendlerindeki kazıkların yüksek olduğu görülmüştü. Ancak bu şekilde bend inşasının esasen değirmencilerin bu konuda yeterince bilgi sahibi olmamalarından kaynaklandığı anlaşıldı. Keza değirmencilerin güz mevsiminde değirmen ve bendlerini tamir ettikleri, bu sırada bendlerin 60 $\mathrm{cm}$ yükseklikte yapılması halinde bahsedilen sorunun ortadan kalkacağı ifade edilmişti. Keza keşif sırasında bendlerin çoğunluğunun tamire ihtiyacı olduğu gözlemlenmiş, söz konusu bendlerin $60 \mathrm{~cm}$ yüksekliğe indirilmesinin az bir masrafla gerçekleştirilebileceği bildirilmişti. Bu suretle bendlerin tamir ve inşası hususunda değirmen sahiplerine komiserlikler tarafından daha önce birer ölçü verilmişti. Ayrıca bendlerin yüksekliği ve düzensizliğinin sadece Osmanlı tarafındaki değirmen bendlerinde olmadığı aynı zamanda Sırp tarafındaki değirmenlerde de mevcut olduğu saptanmıştı. Hatta zikr olunan Crnomasnica ve İzlakok değirmenleri bendinde ve Sirp tarafindaki Milan Kosil ve Jofka Jori isimli Sırpların değirmenlerinin

${ }^{75}$ BOA, HR.SYS., 1393/16, 4-2. 


\section{GÜRSOY ŞAHINN}

bendinin de uygun şekilde inşa edilemediği anlaşılmıştı. Ancak Sırp komiserleri, kendi taraflarındaki değirmen bendi $110 \mathrm{~cm}$ yükseklikte tespit edildiği halde kendi taraflarındaki değirmenlerden hiç bahsetmeyip tamamen Osmanlı tarafındaki değirmenleri kusurlu göstermişlerdi. Üstelik Türk tarafındaki üç adet değirmenin kaldırılması gerektiği şeklinde görüş bildirilmişti.

Esasen meselenin arka planında Timok Nehri'nden Türk tarafının daha fazla fayda sağlaması yatmaktaydı. Raporda ifade edildiği üzere nehir üzerinde ve Türk tarafindan bulunan değirmenlerin sayısı kırk (40) iken Sirbistan tarafinda olanların miktarı on (10) adetti. Dolayısıyla nehirden eskiden beri en çok Osmanlı ahalisi istifade etmekte olup bu durum iki ahali arasında rekabet kaynağı olmaya başlamıştı. Sırp komiserlerinin, süreç içerisinde Osmanlı tarafındaki değirmenleri atıl hale getirerek bilahare nehrin maddi ve manevi menfaatini tamamen kendilerine hasretmek maksadını taşıdıkları kaydedildi.

Raporda gerek arazi gerekse değirmen sahipleri arasında herhangi bir tartı̧̧maya sebebiyet vermeden iki taraf ahalisinin de izin alarak değirmen inşa edebileceği bildirilmekteydi. Bu kapsamda kişiler ilk önce bağlı olduğu hükümete müracaat ederek durumu arz edecekti. Hükümet yetkilileri diğer taraf hükümetiyle haberleşerek birer memur görevlendirecek, kararlaştırılacak günde talep edilen yere memurlar gönderilecekti. Değirmen inşası talep edilen mahalde yapılacak keşif ve inceleme sonucunda herhangi bir mahzur yoksa ve kimseye bir zararın dokunmayacağı anlaşılırsa o vakit değirmenin inşasına izin verilecekti.

Osmanlı komiserleri Timok Nehri'nde suların taşması sebebiyle geçmişte de benzer sorunlar yaşandığını dile getirdi. Bu anlamda nehir zaman zaman mecrasını değiştirmekteydi. Bu durum nehrin tabii akışına göre hem Osmanlı arazisini hem de Sirp arazisini etkilemekteydi. Bu anlamda yukarıda bahsedildiği üzere Adliye kazasına bağlı Berkofça köyü ahalisinin mülkü olan bir miktar arazi 1849 (raporda 1857 kaydedilmiş) yılında Timok Nehri'nin mecrasını değiştirmesinden dolayı Sırbistan tarafına geçmişti. Yaklaşık 1.200 dönüm araziyle ilgili memurlar tarafindan yer tespiti yapılmış, belirli işaretler konularak Berkofça köyü ahalisinin ziraat etmeleri uygun görülmüştü. Osmanlı ahalisinin arazisinde ziraatına ilk etapta Sırp hükümeti tarafından izin verilmişti. Ancak ertesi sene adı geçen köyün on sekiz (18) saat uzağında olan ve Rakovica iskele geçidinde Dinlisan isimli yerden dolaşıp pasaportla geçtikten sonra ziraat etmeleri 


\section{OSMANLI DEVLETI İLE SIRBISSTAN ARASINDA “OYNAK SINIR”: TIMMOK NEHRI'NİN MECRASININ DEĞİŞMESI VE KARŞILAŞILAN SORUNLAR (1849-1874)}

gerektiği ifade edilmişti. ${ }^{76} \mathrm{Bu}$ durumun Osmanlı ahalisini mağdur ettiği, çeşitli zorluklar çıkardığı görülüp uygulanmasının mümkün olamadığı anlaşıldı. Dolayısıyla ahali şahsi arazilerini hukuken kaybetmemek için topraklarında ziraat eden Sirplardan cüzi bir miktar kira almaya başlamışlardı. Raporda söz konusu arazilerin karışmaması için özel işaretler konulması ve sahiplerinin ziraatlarına yeniden izin verilmesi hususunda gereğinin yapılmasının köy ahalisi tarafından talep edildiği bildirilmekteydi.

Benzer bir olay 1869 yılında yaşanmıştı. Adliye kazasına bağlı Crnomasnica köyü ahalisinden birkaç kişinin tapulu arazisi 1869 yılında gerçekleşen mecra değişiminden dolayı Sırp tarafına geçmişti. Tahminen dört yüz (400) dönüm arazinin ziraatına Sırp hükümeti tarafından karşı çıkılmıştı. Bilahare Sırp yetkilileri bizzat köylülerin yanına gelerek araziyi satın almak istedi. Ahalinin satılık arazileri olmadığını söylemesi üzerinde bu sefer araziler tamamen zabt edilmeye başlandi. Bunun üzerine arazi sahipleri sorunun hakkaniyet çerçevesinde çözüme kavuşturulmasını talep etmişlerdi.

Bir başka örnekte Sırplar, Timok Nehri'nin Türk tarafında kalan Ali Şükrü ve Halil Nuri isimli kişilerin tapulu malı olan adadaki çayıra müdahale etmişlerdi. Bu müdahalenin engellenmesi hususunda daha önce Bâbıâli tarafından mülga Belgrad muhafızlığına gerekli tebligatta bulunulmuştu. Keza bu hususta gereğinin yapılması Sadrazamlık makamından daha önceki Vidin valilerinden müteveffa Süleyman Paşa'ya 9 Eylül 1861 tarih ve 15 numaralı evrak ile gönderilmişti. Ancak bahsedilen adaya Sirplar tarafindan el konularak geri verilmedi. Raporda bu durumun da münasip bir şekilde Sırp kapıkethüdasına iletilmesi talep olundu.

Bunun gibi Osmanlı ahalisinin tasarrufunda olan adalara Sirplar tarafından müdahale edildiği, keza sahipleri ne zaman hayvanlarını otlatmaya kalkışsa Sırplar tarafından silah gösterilerek tehdit edildiği bildirilmekteydi. Bu anlamda Adliye kazasına bağlı Graçko köyü arazisinde Hacı Nuri Ağa'nın değirmeninin alt tarafında daha önceden inşa edilen ve nehrin taşması ve sel afeti dolayısıyla tamamen yıkılmış olan değirmenin harkı içerisinde ortaya çıkan adayı da Sırplar zapt etmişlerdi.

Raporda, Sırpların en son nehrin üst tarafına da bir bend inşa ederek Osmanlı topraklarındaki arazinin epeyce bir yerini kendilerine kattıkları

${ }^{76}$ BOA, HR.SYS., 1393/16, 4-2. 


\section{GÜRSOY ŞAHIN}

hatırlatıld1. Komiserlerin ifadelerine göre şayet söz konusu bend oradan kaldırılmayacak olursa taşkın veya sel zamanlarında Sırp tarafına epeyce bir arazinin daha geçmesinin muhtemel göründüğü bildirilirken bu tür usulsüz uygulamalara Osmanlı ve Sırp hükümetlerinin rızasının olup olmadığı soruldu. Keza bu meselede Sirp komiserlerin her türlü muhalefetinin ve uygunsuzluklarının sebebinin hükümetlerinin emri olduğu dile getirildi. Ayrıca Baley köyü yakınından akan Timok Nehri’nin yatağının değiştirilip köyün yakınına alınmasından dolayı şiddetli yağmur yağdığında birkaç haneyi suyun alıp götürmesinin kuvvetle muhtemel olduğu da ifade edildi. Şayet nehir eski mecrasına döndürülmez ise o zaman köyün kısa zaman içerisinde tamamen tahrip olabileceği bildirilerek sorunun halledilmesi talep edildi. $^{77}$

\subsection{Tuna Vilayeti Valisi Abdurrahman Nureddin Pașa'nın} Değerlendirmeleri

Tuna Vilayeti valisi Abdurrahman Nureddin Paşa, ${ }^{78}$ bahsedilen raporlar doğrultusunda konuyla ilgili Sadaret makamına bir yazı yazdı. 7 Şubat 1874 tarihli yazıda, Vidin kazasına bağlı Baley köyü arazisinde bulunan ve Timok Nehri'nin yatağının Sırplar tarafindan değiştirilmesinden dolayı Sırp ve Osmanlı ahalisi arasındaki değirmen bendleri tartışmasının ve Belgradçık kazasına bağlı Vilaçoviç Balkanındaki kaynak bahsinin iki taraftan seçilecek üçer kişilik karma komisyon marifetiyle çözümlenmesi hakkında Vidin mutasarrıflığına 18 Şubat 1873 tarihinde bir emir gönderildiği hatırlatıldı. Bunun üzerine iki taraftan görevlendirilen memurlar birleşerek tartışma konusu olan bölgeye giderek incelemelerini yapmış ve görüşlerini içeren Türkçe ve Sırpça üç adet tahkikat mazbatasını hazırlamışlardı. Mazbatalar ile hazırlanan haritalar birlikte hükümete arz edilmiş ancak evraktan da anlaşılacağı üzere tartışma konusu olan dört adet değirmen hakkında ortak ve kesin bir karara varılamamıştı. Ayrıca diğer değirmenler hakkında Sırp memurlarının beyan ettikleri fikir ve

\footnotetext{
${ }^{77}$ BOA, HR.SYS., 1393/16, 4-3.

${ }^{78}$ Abdurrahman Nureddin Paşa, 1836'da Kütahya'da doğdu. Çeşitli kâtiplik görevlerinden sonra 1864 'te Varna ve 1867 'de Niş mutasarrıflığına tayin oldu. 1872 yılında vezir rütbesi aldıktan sonra 1873 'te Tuna, 1874'te Ankara valiliklerine atandı. Bağdat, Diyarbakır ve tekrar Bağdat valiliği görevinde bulunan Paşa, 1882'de sadrazamlığa getirildi. Bu görevi çok kısa sürdü. Kastamonu, Aydın ve Edirne valilikleri yaptıktan sonra 1895'te Adliye Nazırlığı görevine getirildi. 1912'de hayatını kaybetti. Bkz. Ebubekir Ceylan, "Abdurrahman Nureddin Paşa'nın Osmanlı Irak'ına Dair 1880 Tarihli Lâyihası Üzerine”, Dîvân Disiplinlerarası Çalışmalar Dergisi, Cilt 19, Sayı 37, (2014/2), s. 88-89; Abdulkerim Abdulkadiroğlu, "Abdurrahman Nureddin Paşa", İlmi Araştırmalar, Sayı 13, İstanbul 2002, s. 7-16.
} 


\section{OSMANLI DEVLETI İLE SIRBISSTAN ARASINDA “OYNAK SINIR”: TIMMOK NEHRI'NİN MECRASININ DEĞİȘMESI VE KARŞILAȘILAN SORUNLAR (1849-1874)}

değerlendirmelere Osmanlı memurları katılmamıșlardı. Keza Timok Nehri'nin yatağının değişmesi sebebiyle Sırbistan tarafında kalan arazi ile Vilaçoviç Balkanındaki kaynak tartışmaları hususunda da iki taraf memurları arasında ihtilaf ortaya çıkmıştı. Kesin bir neticeye ulaşılması mümkün olmadığı için kararın verilmesi hükümet yetkililerine havale edilmişti.

Yazıda vurgulandığına göre gerek Osmanlı memurlarının ifadeleri ve değerlendirmeleri ve gerekse haritadaki işaretlerden anlaşılacağı üzere Timok Nehri'nin mecrası Sırpların kasıtlı ve bilerek inşa ettikleri bend sebebiyle değişmişti. Nehrin yatağının değişmiş olması sebebiyle nehrin öte tarafinda kalan yaklaşık beş yüz (500) dönüm arazi Vidin kazasına bağlı Baley köyü ahalisinin tapulu arazileriydi. Sirplar bu durumu bilmekte ve kabul etmekteydi. Keza zikr olunan kaynak mahallinin Sırp sınırına çok uzak olduğu, Sırp memurları tarafindan da onaylanan haritadan anlaşılmaktaydı. Sırp toprakları ile asla irtibatı olmadığı halde Sırplar sınırı aşarak kaynak mahallini çitle çevirmişler ve bölgeyi kendi taraflarına katmak iddiasında olduklarını göstermişlerdi. Abdurrahman Nureddin Paşa, Sirpların, Osmanlı tarafındaki arazi sahiplerinin tasarrufunda olan yerlerde kesinlikle hakları olmadığı halde müdahalede bulunduklarını ve bilerek ahalinin birbirine karşı düşmanlığına sebebiyet verdiklerini ifade etmekteydi. Sonuç olarak hükümetten adaletin temin edilmesi talep edilmekteydi. ${ }^{79}$

Abdurrahman Nureddin Paşa yazısının devamında Timok Nehri üzerinde bulunan değirmenlerden tartışma konusu olan dördünden hariç diğer değirmenler hakkında Sırp memurların beyan edecekleri fikir ve değerlendirmelerin doğrudan Bâbıâli'ye arz ve takdim edilmesi gerektiği hususuna değinmekteydi. Bununla ilgili 8 ve 17 Eylül 1873 tarihlerinde gönderilen yazılarda ve çekilen telgrafla verilen emir hatırlatıldı. Bu hususta ortak şekilde kaleme alınan tahkikat mazbatasında Osmanlı memurları tartışma konusu olan dört değirmen dışında kalan değirmenler hakkında mütalaada bulunmaya izinleri olmadığını bildirmiş ve kaleme alınan layihayı ekte sunmuşlardı. Söz konusu layihada Sırp memurlarının gerek tartışmalı dört değirmen hakkında beyan edecekleri fikir ve değerlendirmeler ve gerekse Sırpların sınır hattında gerçekleşen tecavüzkârane hareketlerinin engellenmesi ve incelemelerin sonuçlandırılmasının mümkün olmadığı bildirilmişti. Bu sebepten sorunun

${ }^{79}$ BOA, HR.SYS., 1393/16, 5-1. 


\section{GÜRSOY ŞAHINN}

çözümü konusunda Bâbıâli'den gelecek emre göre hareket edileceği kaydedildi. $^{80}$

Yukarıdaki yazının üzerinden birkaç ay geçtikten sonra 3 Mayıs 1874 tarihinde Rusçuk'tan Sadaret makamına bir telgrafname gönderildi. Telgrafta, Timok Nehri ile ilgili oluşturulan komisyonunun 358 numara ve 8 Şubat 1874 tarihli sonuç raporu ile evrakın takdim edildiği ancak henüz bir cevap ulaşmadığı ifade edilmekteydi. Yazıda tartışmalı Vilaçoviç Balkanındaki kaynağın eski çitinin Sırplar tarafından şimdi yenilenmeğe çalışıldığının Vidin mutasarrıflığından bildirildiği, buna karşılık nasıl bir işlem yapılacağı hususunda acilen bilgi verilmesi istenmişti. ${ }^{81}$

\section{8. İstanbul'daki Komisyonun Nihai Raporu}

Gerçekleştirilen keşif ve incelemeler sonucu hazırlanan mazbata ve haritalar ile diğer evrak Bâbıâli'ye ulaştı. Sorun 31 Aralık 1874 tarihinde nihai olarak incelenmek ve karar verilmek üzere komisyona havale edildi. Komisyon, araziye dair olan hususları daha önemli gördüğünden ilk olarak bu belgeler incelendi. Komisyonun harita ve evraktan anladığı Timok Nehri'nin mecrasını değiștirerek Baley köyünün arazisini ayırmasının sebebi Sırp ahalisinden Yuvan İstifanoyik ile ortağı tarafından işletilen değirmenin bendiydi. Baley köyü ahalisi ise suyu eski mecrasına döndürmeye çalışmışlardı. Ancak Sırplar buna izin vermeyerek bendi yıkmışlardı. Sırplar, nehrin yatağını değiştirmek için bir sed yaparken hukuka aykırı olarak Baley köyü arazisine bir de karakol inşa etmişlerdi. Buna karşıllk Sırp memurları, Yuvan İstifanoyik'in değirmeninin mevki ve mahallinin uzaklığından ve köy değirmeninin bendinin aşağısında bulunduğundan bahisle bunun hiçbir suretle mecra değişikliğine etkisi olamayacağını, nehrin eski yatağının dolmasına da sebebiyet vermeyeceğini bildirmekteydi. Keza bölgeye yeni bir karakol inşasının Timok Nehri'nin Sırbistan tarafını ayırmas1 ve sınırın muhafazası düşüncesine dayandığı ifade edilmekteydi. Dolayısıyla buraların Bâbıâli ile Sırp emareti arasında bir karar verilip sınır tespit oluncaya kadar çit çekilmesinden vazgeçilse de geçici hudud kabul edildiği ifade edildi. ${ }^{82}$

\footnotetext{
${ }^{80}$ BOA, HR.SYS., 1393/16, 6-1.

${ }^{81}$ BOA, HR.SYS., 1393/16, 8-1; BOA, HR.SYS., 1393/16, 9-1.

${ }^{82}$ BOA, HR.SYS., 1407/3, 1-1.
} 


\section{OSMANLI DEVLETI İLE SIRBISSTAN ARASINDA “OYNAK SINIR”: TIMMOK NEHRI'NİN MECRASININ DEĞİSMESİ VE KARŞILAŞILAN SORUNLAR (1849-1874)}

Sonuç olarak komisyon harita ve raporlara dayanarak Sırp ahalisinden İstifanoyik'in inşa etmiş olduğu değirmenin bendinin, nehrin yatağını doldurduğu ve suyun akışını engelleyerek mecrasını değiştirmesine sebep olduğu kanaatine vardı. Keza Baley köyü ahalisinin, hukuklarını korumak maksadıyla inşasına başladıkları bendin Sırplar tarafından yıkılması haksızlıklarını ortaya koymaktaydı. Nehrin eski mecrasına çevrilmesi ise çok zor şartlarda mümkün görünmekteydi. Nehrin ayırdığı arazi dört yüz seksen (480) dönüm (raporda dört yüz (400)) olup, Sirpların buralara el koymaya niyetli olduğu anlaşılmaktaydı. Komisyon üyeleri, Baley köyü ahalisinin bu araziye şiddetle ihtiyacı olduğunu ifade etmekteydi. Keza arazinin Sırplara bırakılması halinde gelecekte çeşitli problemlerin ortaya çıkacağı da Tuna Vilayetinden bildirilmekteydi. Komisyona göre bahsedilen arazi belirli bir bedel ile Sırp tarafına bırakılıp, bedeli karşılığı alınacak para, ahaliye arazileri nisbetinde dağıtılabilirdi. Ancak son karar yine de hükümete bırakıldı. ${ }^{83}$

$\mathrm{Bu}$ süreç devam ederken 1875 'te patlak veren Balkan Bunalımı ve ardından yaşanan 1877-1878 Osmanlı-Rus Savaşı şartları değiştirdi. Berlin Antlaşması sonrası Sırbistan bağımsızlığını kazanırken Tuna ile Balkanlar arasında Sofya, Niğbolu, Ziştovi, Rusçuk, Silistre, Varna, Şumnu, Lofça ve Tırnova gibi şehirleri içine alan muhtar bir Bulgaristan Prensliği de kuruldu. ${ }^{84}$ Osmanlı Devleti ile Sirbistan arasında sinır olarak kabul edilen Timok Nehri, Bulgar Prensliği kurulduktan sonra Sirbistan ile Bulgar Prensliği arasında sınır olma özelliliğini devam ettirdi. Dolayısıyla sınırla ilgili tartışmalar bu tarihten sonra Sırbistan ile Bulgar Prensliği arasında yaşanmaya başlandı. Bu anlamda 1886 yılında yaşanan sınır tartışmalarında Bulgar emareti Osmanlı Devleti'nden geçmişteki uygulamalara dair görüş ve belge talep etti. ${ }^{85}$ Konu 1888 'de Meclis-i Vükela'da müzakere edildi. Sonuçta Timok Nehri'nin akış yönüne göre sağ ${ }^{86}$ tarafında bulunan ve

${ }^{83}$ BOA, HR.SYS., 1407/3, 1-2.

${ }^{84}$ Yusuf Halaçoğlu, "Bulgaristan-Osmanlı Dönemi”, DİA, Cilt 6, TDV Yay., İstanbul 1992, s. 398; Esasen Berlin Anlaşması, bu tarihten sonra ortaya çıkacak Balkan bunalımlarının temelini oluşturmuştu. Eski Sırbistan'ın yeniden kurulma düşüncesi, Bulgaristan'ın Balkanlarda bir birlik oluşturma hedefi Balkan Savaşlarını hazırlayan nedenler olarak belirmeye başladı. Feyza Kurnaz Şahin, "İngiliz Büyükelçiliği Yıllık Raporlarında Balkan Savaşları ve Türkiye (1912-1913)”, Uluslararası Sosyal ve Eğitim Bilimleri Dergisi, Cilt 5, Sayı 10, (Aralık 2018), s. 288.

${ }^{85}$ BOA, HR.TO., 19/171, 1-1; BOA, HR.TO. 19/171, 1-2; BOA, A.MKT.MHM., 493/11, 1-1; BOA, A.MKT.MHM., 493/11, 2-1; BOA, A.MKT.MHM., 493/11, 3-1.

${ }^{86}$ Bir nehrin sağı veya solunun, nehrin kaynağından akış yönüne göre tanımlanmaktadır. Aydın, a.g.e., s. 16. 


\section{GÜRSOY ŞAHIN}

Surbistan'a ait olan Bregovo merasının Bulgaristan emaretine ve nehrin sol tarafında bulunan Baley merasının da Sırbistan hükümetine terk edilmesine karar verildi ${ }^{87}$ Ancak sorun ilerleyen zamanlarda örneğin $1892^{88}$ ve 1901 yıllarında tekrar gündeme geldi. Zira Bulgaristan komiserliği, Osmanlı hükümetine Timok üzerindeki değirmenlerden kaynaklanan problemleri iletmeye devam etti. ${ }^{89}$

\section{Sonuç}

Surbistan'ın muhtariyeti 1830 'da verilen bir imtiyaz fermanıyla tanınmış ve Timok Nehri, Osmanlı topraklarıyla sınır olarak tespit edilmişti. Ancak arşiv belgeleri ışığında yapmış olduğumuz bu çalışma neticesinde Timok Nehri'nin aşırı yağmurlar sonucu taşması nedeniyle önemli bir sınır probleminin ortaya çıtı̆̆ 1 anlaşılmaktadır. "Oynak sınır" olarak nitelendirilebilecek nehir, taşkınlar sonucunda yatak değiştirmiş ve buna bağlı olarak Osmanlı ahalisinin toprakları Sırp tarafında kalmıştı. Bu anlamda 1849 yılında aşırı yağmurlar sebebiyle Timok Nehri'nin taşdığı, bunun sonucunda nehrin yatağının değiştiği ve Berkofça köyünden altmış üç kişinin tarla ve çayırlarının Sırbistan tarafında kaldığından söz edilmekteydi.

Timok Nehri'nin taşması, aşırı yağan yağmurlar kadar nehir kenarında faaliyet gösteren değirmen bendlerin usulüne uygun yapılmamasına da bağlanmaktaydı. Örneğin 1862 yılında Osmanlı ahalisinin Rakofça-i Sağir köyü yakınında ve Timok Nehri üzerinde inşa ettikleri değirmen bendi, taşkına sebep olduğu gerekçesiyle Sırplar tarafından yıkıldı. Anlaşılacağı üzere Osmanlı Devleti muhtariyetini tanıdığı Sırbistan ile sınır meselesini tam anlamıyla çözüme ulaştıramamış, mesele sürüncemede bırakılmıştı. Ancak nehrin yatak değiştirmesi sonucu ortaya çıkan arazi meselesi, Osmanlı ve Sirp ahalisi arasında ihtilafa sebebiyet vermeye devam etti.

Araştırmada görüldüğü üzere tarafları en fazla meşgul eden husus 1872 yılında Sırpların Timok Nehri'nin doğal mecrasını değiştirerek kendi taraflarında kalan Baley köyü arazisine müdahalelerinin ortadan kaldırılması meselesi oldu. Osmanlı ve Sırp tarafları bölgedeki huzurun bozulmaması ve

\footnotetext{
${ }^{87}$ BOA, $M V ., 36 / 9,1-2$.

${ }^{88}$ BOA, HR.SFR.04, 733/24, 1-1; BOA, HR.SFR.04, 341/24, 1-1.

${ }^{89}$ BOA, Y.A.HUS., 417/51, 2-1.
} 
OSMANLI DEVLETİ İLE SIRBISSTAN ARASINDA “OYNAK SINIR": TIMMOK NEHRI'NİN MECRASININ DEĞIŞMESİ VE KARŞILAŞILAN SORUNLAR (1849-1874)

ahali arasında yaşanabilecek çatışmaları önlemek için karma komisyonlar kurarak meseleyi çözmeye çalıştı. Ancak komisyon üyeleri kendi görüşlerini savundu ve mesele tam anlamıla bir çözüme ulaştırılamadı.

Konuyla ilgili tüm rapor ve haritalar Bâbıâli'nin kurduğu komisyonca incelendikten sonra bir kanaat oluştu. Buna göre 1872 yılında nehrin mecrasını değiştirmesinin sebebi Sırp ahalisinden İstifanoyik' in inşa etmiş olduğu benddi. Komisyon, nehrin Osmanlı topraklarından ayırdığı arazinin dört yüz seksen dönüm olması nedeniyle Sirpların bu araziye el koyma niyetinde oldukları kanaatine vard1. Arazinin Sirplara birakılmas1 halinde gelecekte çeşitli problemlerin ortaya çıkacağı da anlaşıldı. Yapılan değerlendirmeler sonucunda arazinin belirli bir bedel karş1lığında Sırp tarafına bırakılması ve alınacak paranın da arazileri nisbetinde ahaliye dağıtılmasının uygun olacağı ifade edildi. Burada Sırp yönetimi ve ahalisinin bağlılığına halel getirmemek için bu yönde bir görüş bildirildiği anlaşılabilir.

Komisyonun kararına rağmen sorun tam anlamıyla çözüme kavuşturulamadı. Zira 1875'te başlayan Balkan Bunalımı ve 1877-1878 Osmanl1-Rus Savaş1 bütün dengeleri değiştirdi. Sorun, Berlin Antlaşmasından sonra Sırbistan ile Bulgar Prensliği arasında sorun teşkil etmeye devam etti. En nihayetinde Bulgaristan ile Surbistan arasındaki ihtilaf, Timok Nehri'nin sağının Bulgaristan'a solunun ise Sırbistan'a terki suretiyle çözümlendi.

\title{
KAYNAKÇA
}

\author{
A. Arşiv Kaynakları \\ 1. Cumhurbaşkanlığı Devlet Arşivleri Başkanlığı Cumhuriyet Arşivi \\ (BCA) \\ 030.10.00.00/251.696.11.7. Tarih: 24.06.1933. \\ 030.10.00.00/251.696.11.8. \\ 2. Cumhurbaşkanlığı Devlet Arşivleri Başkanlığı Osmanlı Arşivi (BOA) \\ A.AMD., 41/20.001.001, Tarih: H-09-02-1269. \\ A.MKT., 163/47, 1-1, Tarih: 16-06-1265; 196/49, 1-1; 196/49, 2-1; 196/49, \\ 3-1; 196/49, 4-1, Tarih: 16 S 1265.
}




\section{GÜRSOY ŞAHINN}

A.MKT.MHM., 493/11.001.001; 493/11.002.001; 493/11.003.001, Tarih: H09-04-1304.

A.MKT.NZD., 00068/00005.001.001, Tarih: H-23-02-1269.

HR.MKT., 238/99, 1-1, Tarih: 10 L 1274; 248/90, 1-1; 248/90, 1-2, Tarih: H-20-12-1274; 411/43, Tarih: H-28-03-1279; 437/32, 24, Tarih: 11 Rebiülahir 1289; 437/32, s. 3, Tarih: H-28-11-1279; 775/71, s. 3, Tarih: 4 Zilkaade 1289; 775/71, s. 4, Tarih: 15 Haziran 1288; 775/71, s. 5, Tarih: 11 Cemaziyelahir 1289; 775/71, s. 6, Tarih: 2 Kanunuevvel 1288; 775/71, s. 8, Tarih: 12 Teşrinievvel 1288; 797/48, Tarih: H-21-06-1290; 800/98, Tarih: H-16-07-1290.

HR.SFR.04, 341/24, 1-1, Tarih: 4 Muharrem 1310; 733/24, 1-1, Tarih: 24 Zilhicce 1309.

HR.SYS. 1393/17.7.1; 1393/16.4.1; 1393/16.4.2; 1393/16.5.1; 1393/16.6.1, 20 Zilhicce 1290; 1393/16.8.1; 1393/16.9.1; 1393/17-6-1, Tarih: 9 Kanunevvel 1289; 1393/17-6-3, Tarih: 2 Zilkade 1290; 1393/17.7.1; 1393/17.7.3, Tarih: 1 Zilkade 1290; 1393/16.1.1, Tarih: 28 Şevval 1289; 1393/16.2.1; 1393/16.3.1, Tarih: 23 Cemaziyelahir 1290; 1393/16.4.1; 1393/16.4.2; 1393/16.4.3, Tarih: 7 Zilkade 1290; 1393/16.7.1, Tarih: 24 Şevval 1289; 1393/17.1.1, Tarih: 18 Cemaziyelahir 1290; 1393/17.3.1, Tarih: 4 Recep 1290; 1393/17-3-1, Tarih: 2 Rebiülevvel 1290; 1393/17.6.2; 1393/17.7.2; 1407/1.1.1, Tarih: 18 Cemaziyelahir 1290; 1407/3-1-1; 1407/3.1.2, Tarih: M-31-12-1874.

HR.TO. 19/171-1-2, Tarih: 31 Kanunuevvel 1886; 19/171-1-1, Tarih: 31 Kanunuevvel 1886.

HRT.h., 261/1, Tarih: H-10-08-1269.

I.DH., 262/16258.001.001 Tarih: 23 Muharrem 1269; 262/16258.002.001, Tarih: 9 Safer 1269.

MV., 36/9.001.002, Tarih: H-16-01-1306.

Y.A.HUS., 417/51.002.001, Tarih: 12 Rebievvel 1319.

\section{B. Salnâmeler}

Salnâme-i Vilayet-i Tuna, 1. Defa, Tuna Vilayeti Matbaas1, 1285/1868.

Salnâme-i Vilayet-i Tuna, 6. Defa, Matbaa-i Vilayet-i Tuna, Rusçuk 1290/1873.

\section{Kitap, Makale ve Diğer Kaynaklar}

ABDULKADİROĞLU, Abdulkerim, "Abdurrahman Nureddin Paşa", İlmi Araştırmalar, S. 13, İstanbul 2002, ss. 7-16. 
OSMANLI DEVLETİ İLE SIRBISTTAN ARASINDA “OYNAK SINIR": TIMOK NEHRİNIIN MECRASININ DEĞİŞMESİ VE KARŞILAŞILAN SORUNLAR (1849-1874)

APAYDIN, Bahadır, "5 Aralık 1857 Tarihli Osmanlı Devleti-Rusya Sinır Anlaşması", Uluslararası Hukuk ve Politika, Cilt 5, Sayı 18, 2009, ss. 83103.

AYDIN, Mahir, Vidin Kalesi: Tuna Boyu'ndaki İnci, Ötüken Yay., İstanbul 2015.

BRANKOV, Jovana - MILIJAŠEVIĆ, Dragana - MILANOVIĆ, Ana, "The Assessment of The Surface Water Quality Using The Water Pollution Index: A Case Study of The Timok River (The Danube River Basin), Serbia", Archives of Environmental Protection, Vol.38, No.1, 2012, ss. 49-61.

CEYLAN, Ebubekir, "Abdurrahman Nureddin Paşa'nın Osmanlı Irak'ına Dair 1880 Tarihli Lâyihası Üzerine", Dîvân Disiplinlerarası Çalışmalar Dergisi, Cilt 19, Say1 37, (2014/2), ss. 85-115.

DURAN, Nurbanu, Strbistan Emareti Öncesi Belgrad: 1792-1830, İstanbul Üniversitesi Sosyal Bilimler Enstitüsü, Basılmamış Doktora Tezi, Prof. Dr. Mahir Aydın, İstanbul 2019.

HAJEK, A., "Sirbistan", İslam Ansiklopedisi, 10, MEB Yayınlar1, İstanbul 1980, ss. 556-566.

HALAÇOĞLU, Yusuf, "Bulgaristan-Osmanlı Dönemi", DIA, Cilt 6, TDV Yay., İstanbul 1992, ss. 396-399.

JELAVİCH, Barbara, Balkan Tarihi, 18-19. Yüzylllar, çev. İ. Durdu-H. Koç-G. Koç, 2. Baskı, Küre Yay., İstanbul 2009.

KAYAPINAR, Ayşe, "Ortaçağ ve Osmanlı Döneminde Vidin", Ege ve Balkan Araştırmaları Dergisi, Cilt 2015, Sayı 1, ss. 67-114.

KİEL, Machiel, "Vidin", DİA, Cilt 43, TDV Yay., İstanbul 2013, ss. 103106.

KURNAZ ŞAHİN, Feyza, "İngiliz Büyükelçiliği Yıllık Raporlarında Balkan Savaşları ve Türkiye (1912-1913)", Uluslararası Sosyal ve Ĕgitim Bilimleri Dergisi, Cilt 5, Say1 10, (Aralık 2018), ss. 286-307. 


\section{GÜRSOY ŞAHIN}

KURT, Halil - HACISALIHHOĞLU, Mehmet, "Surbistan", Di்A, Cilt 37, TDV Yay., İstanbul 2009, ss. 120-126.

KURTARAN, Uğur, "Pasarofça Antlaşması'na Göre Yapılan Sınır Tahdit Çalışmaları ve Belirlenen Yeni Sınırlar”, Uluslararası Sosyal Araştırmalar Dergisi, Cilt 11, No. 55, (Şubat 2018), ss. 285-300.

PİİĆ, Radmila - STANOJKOVİ́C-SEBİ́, Aleksandra - DINIIĆ, Zoran MAKSIMOVİ́, Jelena - PEŠİ́, Milan - JOŠİC, Dragana, "Water from the Timok River in Serbia: Estimation of Its Suitability for Arable Soil Irrigation", 23rd International Symposium on Analytical and Environmental Problems, October 9-10, 2017, Editörler: Tünde Alapi - István Ilisz, Szeged Hungary 2017, ss. 283-288. http://www2.sci.uszeged.hu/isaep/index_htm_files/Proceedings_of_ISAEP_2017.pdf, (04.09.2020).

SELÇUK, Hava, Tuna Boyunda Bir Osmanlı Kenti Vidin -XIX.Yüzyll-, Çizgi Kitabevi, Konya 2013.

TURAN, Şerafeddin, "1829 Edirne Antlaşması", Ankara Üniversitesi Dil ve Tarih-Coğrafya Fakültesi Dergisi, Cilt 9, Sayı 1-2, 1951, ss. 111-151.

United Nations Economic Commission for Europe, Rainer Enderlein, Our Waters: Joining Hands Across Borders: First Assessment of Transboundary, https://www.unece.org/fileadmin/DAM/env/water/blanks/assessment/assess mentweb_full.pdf, (03.09.2020).

UZUNÇARŞILI, İsmail Hakkı, Osmanlı Tarihi, (Karlofça Antlaşmasından XVIII. Yüzyllın Sonlarına Kadar), Cilt IV, 1. Kısım, 7. Baskı, TTK Yay., Ankara 2011.

ÜSTÜNDAĞ ÖZDEMIR, Nagehan, 18. Yüzyılda Vidin Şehrinin SosyoEkonomik Panoramass (1790-1808), Hacettepe Üniversitesi Sosyal Bilimler Enstitüsü, Basılmamış Doktora Tezi, Danışman: Prof. Dr. Yunus Koç, Ankara 2014. 
OSMANLI DEVLETI ILE SIRBISTAN ARASINDA “OYNAK SINIR": TIMOK NEHRI'NIN MECRASININ DEĞİŞMESİ VE KARŞILAŞILAN SORUNLAR (1849-1874)

\section{Ekler}

Ek-1 Timok Nehri'nin Mecrasının Değişmesi Üzerine 19 Mayıs 1853'te Berkofça Köyü Arazisini Gösteren Harita

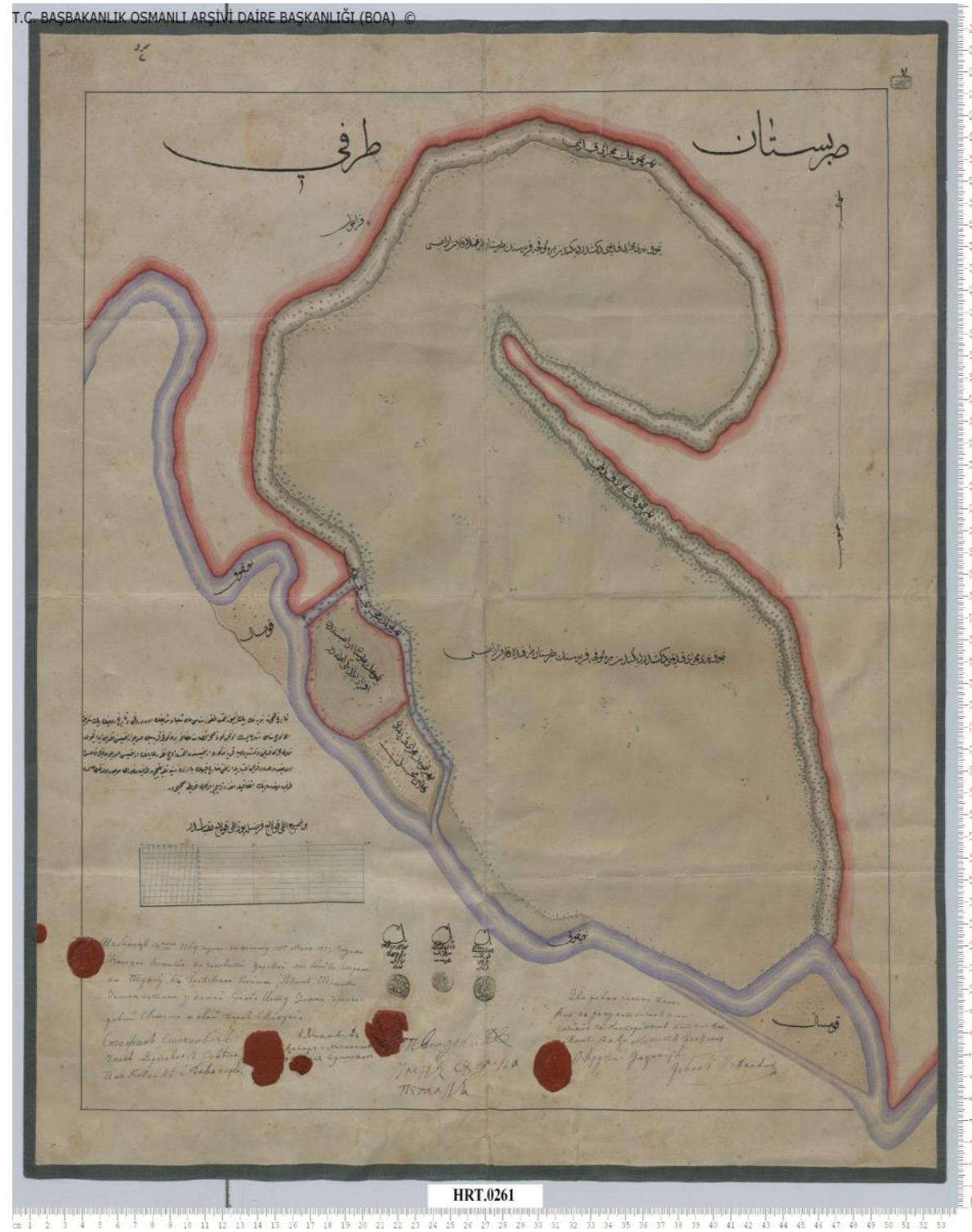

BOA, HRT.h., 261/1. 


\section{GÜRSOY ŞAHİN}

Ek-2 Timok Nehri'nin Mecrasının Değişmesi Üzerine 12 Ağustos 1873 'te Baley Köyü Arazisini Gösteren Harita

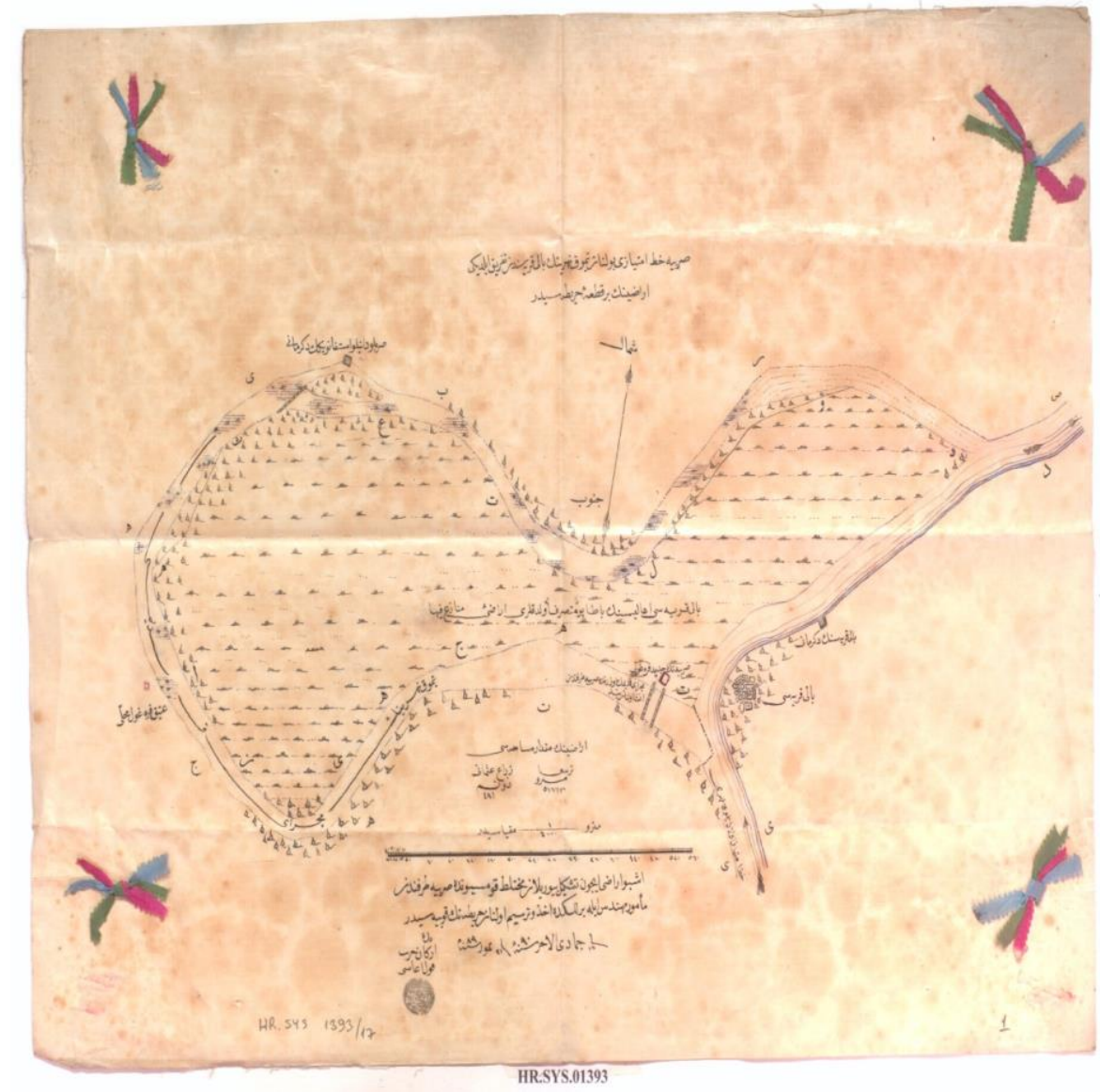

BOA, HR.SYS., 1393/17.1.1. 
OSMANLI DEVLETI İLE SIRBISSTAN ARASINDA “OYNAK SINIR”: TIMMOK NEHRI'NİN MECRASININ DEĞİŞMESİ VE KARŞILAŞILAN SORUNLAR (1849-1874)

Ek-3 Timok Nehri'nin Mecrasının Değișmesi Üzerine 12 Ağustos 1873’te Baley Köyü Arazisini Gösteren Sırpların Elindeki Harita

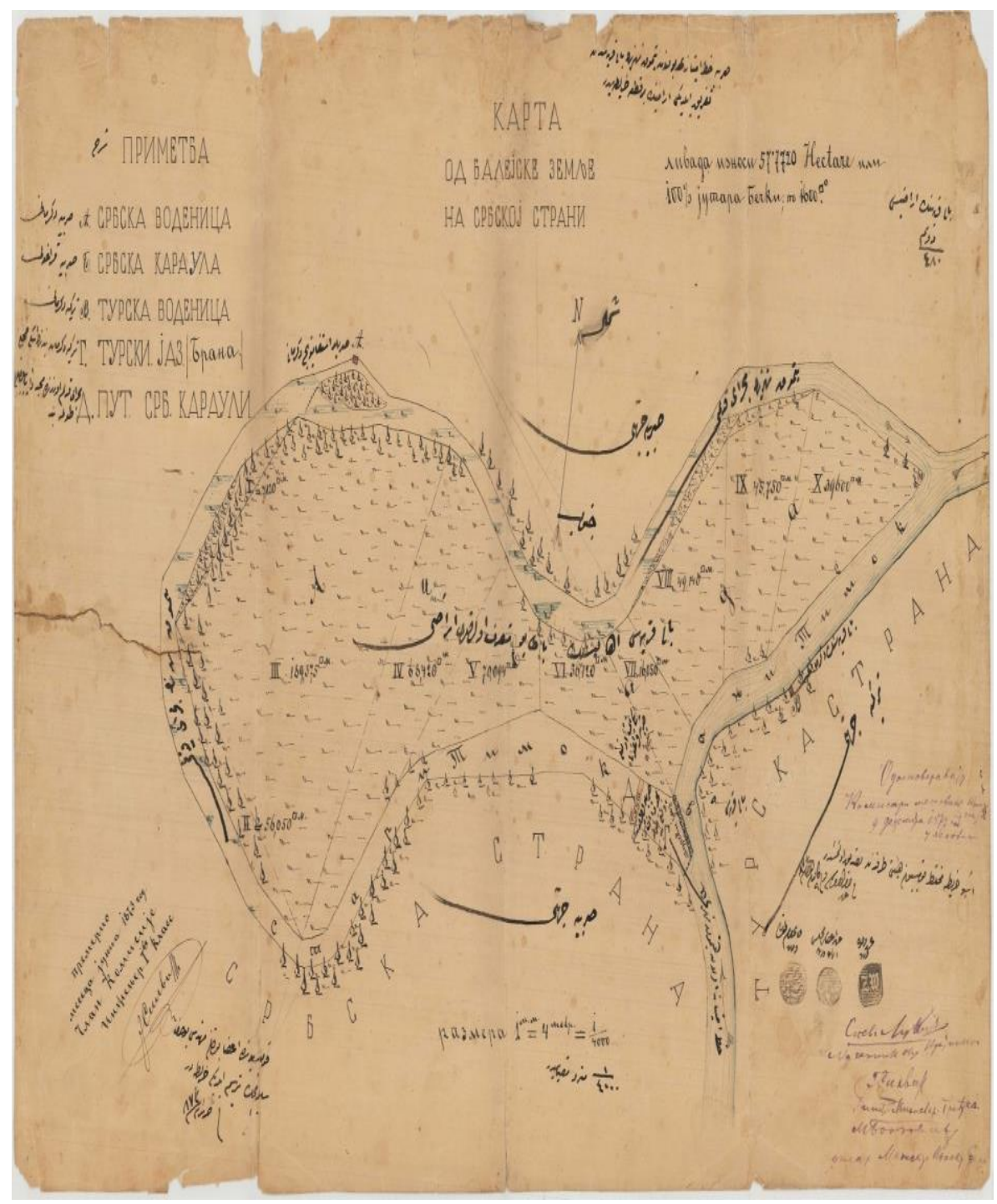

https://www.pahor.de/maps-and-prints/europe/timok-bulgaria-serbia-karta-od-bale-ske-zeme-na-srbsko-strani-karta-od-balejske-zemlje-na-srbskoj-strani.html, (26.08.2020). 


\section{GÜRSOY ŞAHİN}

Ek-4 Timok Nehri'nin Mecrasının Değişmesi Üzerine 16 Ağustos 1873’te Baley Köyü Arazisini Gösteren Harita

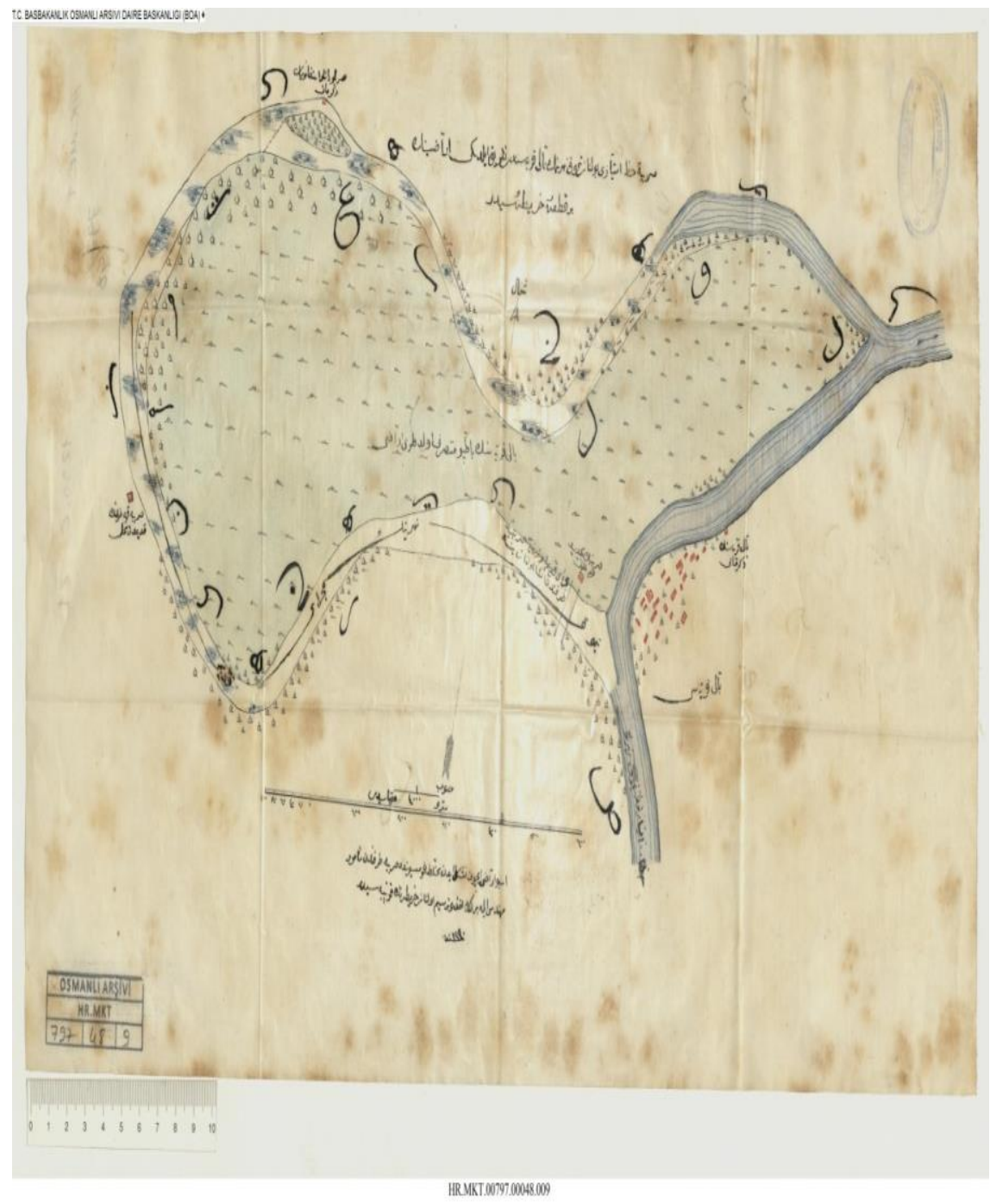

BOA, HR.MKT., 797/48, 9-1. 
OSMANLI DEVLETİ İLE SIRBISTAN ARASINDA “OYNAK SINIR”: TIMOK NEHRI'NİN MECRASININ DEĞİŞMESİ VE KARŞILAŞILAN SORUNLAR (1849-1874)

Ek-5 Timok Nehri’nin Mecrasının Sırplarca Değiştirilmesiyle Sırp Tarafinda Kalan Baley Köyü Arazisini Gösteren 15 Kasım 1873 Tarihli Harita

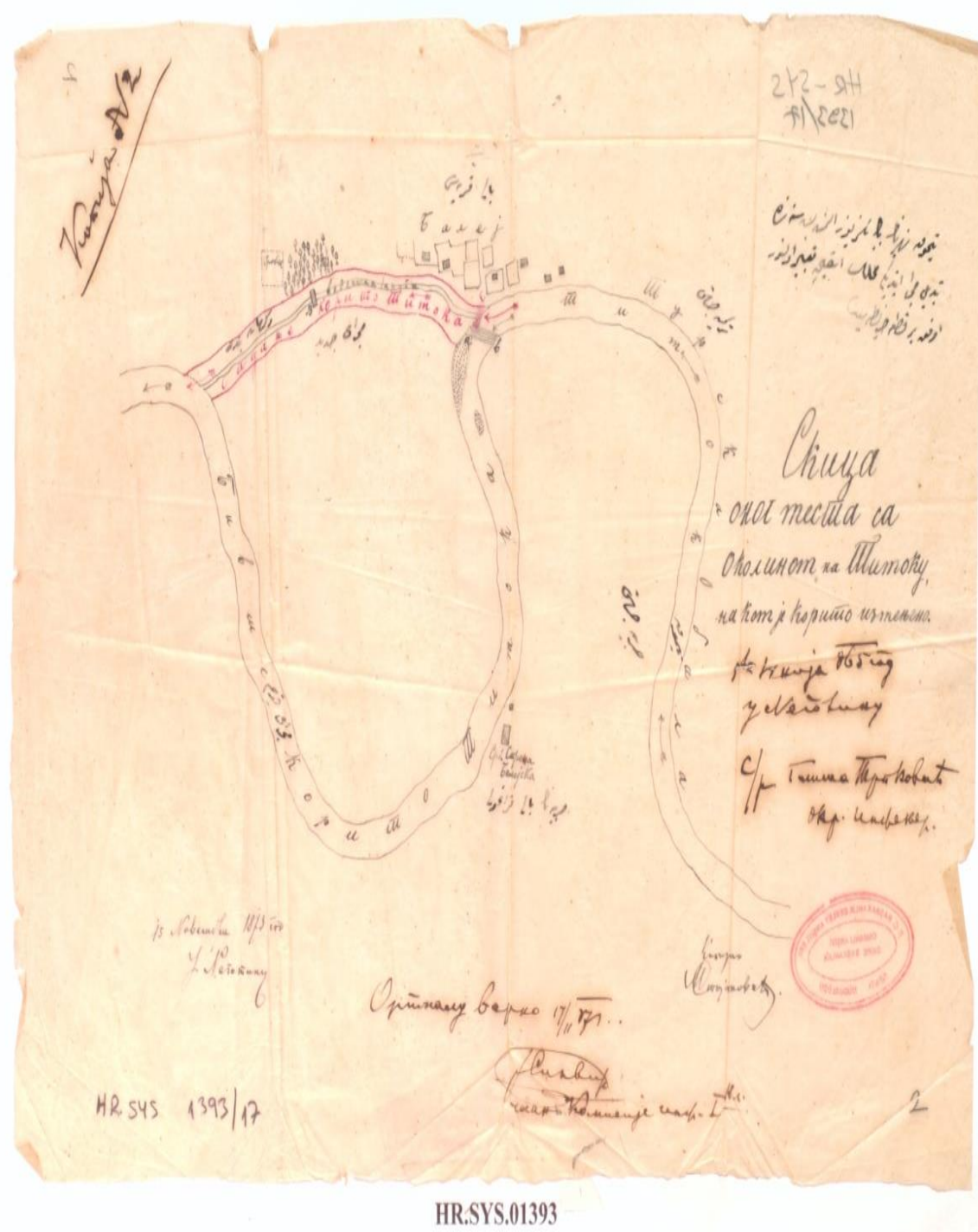

BOA, HR.SYS., 1393/17.2.1 


\section{GÜRSOY ŞAHİN}

Ek-6 Vilaçoviç Balkanındaki Kaynak Mahallinin 3 Ekim 1873’teki Durumunu Gösteren Harita

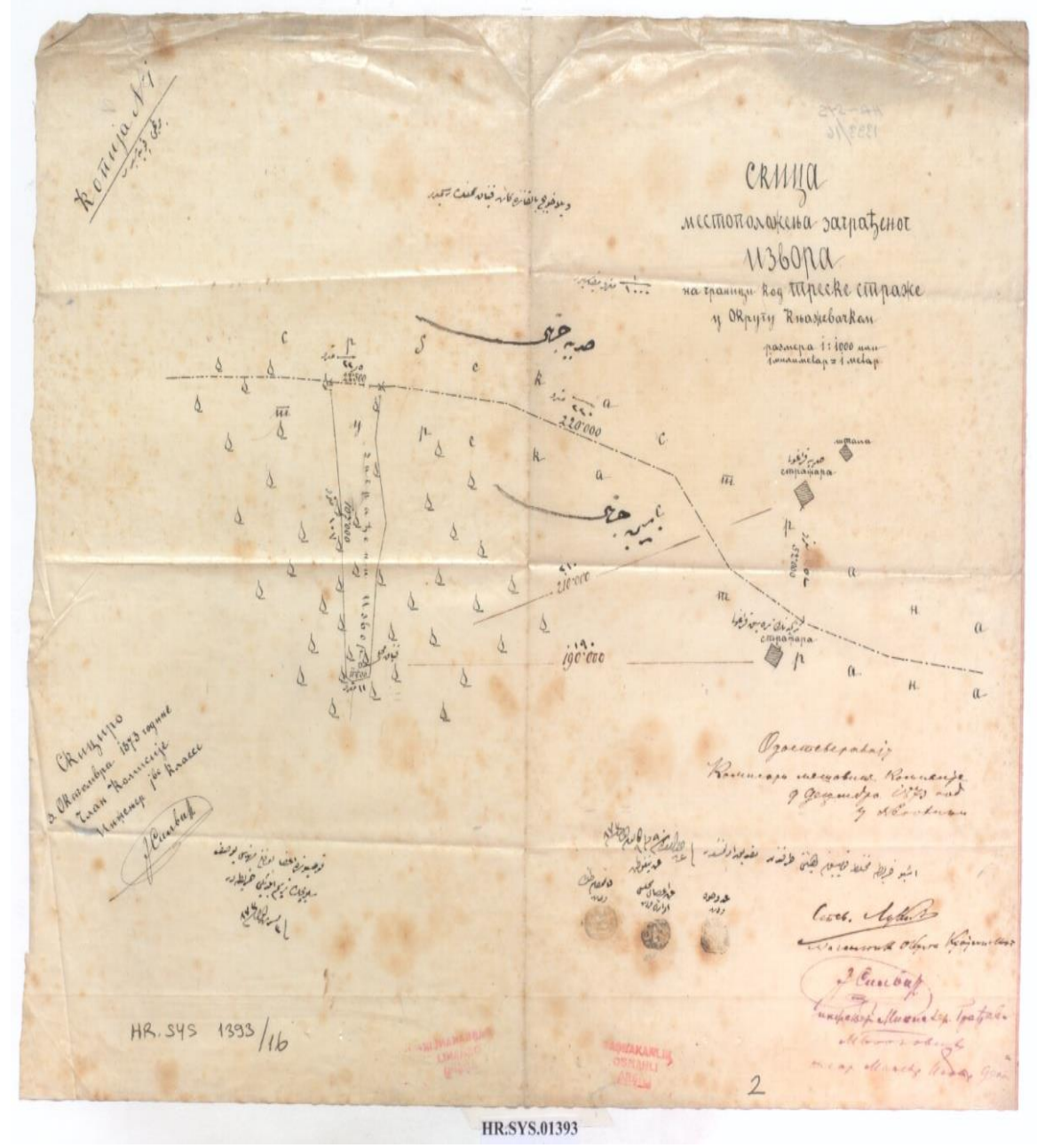

BOA, HR.SYS., 1393/16.2.1. 